\title{
21. ORIGIN AND GEOCHEMISTRY OF CRETACEOUS DEEP-SEA BLACK SHALES AND MULTICOLORED CLAYSTONES, WITH EMPHASIS ON DEEP SEA DRILLING PROJECT SITE 530, SOUTHERN ANGOLA BASIN ${ }^{1}$
}

\author{
Walter E. Dean, U.S. Geological Survey, Denver, Colorado \\ Michael A. Arthur, ${ }^{2}$ Department of Geology, University of South Carolina, Columbia, South Carolina \\ and \\ Dorrik A. V. Stow, Grant Institute of Geology, University of Edinburgh, \\ Edinburgh, Scotland, EH9 3JW, United Kingdom
}

\begin{abstract}
Deep-water sedimentary sequences of mid-Cretaceous age, rich in organic carbon, have been recovered at many DSDP sites in the Atlantic Ocean. Most of these sequences have a marked cyclicity in amount of organic carbon resulting in interbedded multicolored shale, marlstone, and (or) limestone that have cycle periods of 20,000 to 100,000 years and average 40,000 to 50,000 years. These cycles may be related to some climatic control on influx of terrigenous organic matter and sediment, rates of upwelling and sea-surface production of organic matter, and preservation of organic matter related to deeper-water dissolved oxygen concentration. These variations in supply of organic matter had pronounced effects on the potential of the sediment for subsequent diagenetic changes and geochemical partitioning in adjacent beds.

Many trace elements are enriched in organic-carbon-rich lithologies relative to interbedded organic-carbon-poor lithologies. Elements that are most commonly enriched are $\mathrm{Cr}, \mathrm{Ni}, \mathrm{V}, \mathrm{Cu}, \mathrm{Zn}$, and $\mathrm{Mo}$. The association of high traceelement concentrations with organic matter may be the result of concentration of these elements by organisms or by chemical sorption and precipitation processes under anoxic conditions. Detailed trace-element profiles from organiccarbon-rich strata at Site 530 suggest that there may be differential mobility of trace elements, with diffusion of some elements over distances of at least tens of meters. The sequence of trace-element mobility, from highest to lowest, is approximately $\mathrm{Ba}, \mathrm{Mn}, \mathrm{Pb}, \mathrm{Ni}, \mathrm{Co}, \mathrm{Cr}, \mathrm{Cu}, \mathrm{Zn}, \mathrm{V}, \mathrm{Cd}$, and $\mathrm{Mo}$. Slowly deposited, oxidized clays directly overlying some black shale sequences are enriched in some metals, particularly $\mathrm{Fe}, \mathrm{Mn}, \mathrm{Zn}$, and $\mathrm{Cu}$, relative to normal pelagic clays, and this enrichment may be the result of upward migration of metals in pore waters during compaction or diffusion from the underlying black shale.

Most depositional models that have been used to explain the accumulation of the organic-carbon-rich strata imply that reducing conditions in the sediments (and therefore the increased degree of preservation of organic matter) were the result of anoxic or near-anoxic conditions in oceanic bottom waters, or in a midwater oxygen-minimum zone. Evidence from several DSDP sites in the Atlantic, however, indicate that some of these middle Cretaceous "black shale" beds may be the result of variations in rate of supply of organic matter that produced anoxia or near-anoxia within midwater oxygen-minimum zones and possibly, under extreme conditions, throughout much of the bottomwater mass. Although bottom-water anoxia may have occurred during periods of organic-carbon-rich strata, it was not necessarily the only cause for accumulation of these strata. The main reason for the accumulation of organic-carbonrich strata was an increase in the relative amount of organic debris being deposited. Some of this organic debris was derived from continental-margin areas of increased production, accumulation, and preservation of organic matter from marine, terrestrial, or mixed sources and transported to slope and basinal sites by turbidity currents.
\end{abstract}

\section{INTRODUCTION}

Deep-water sedimentary sequences of middle Cretaceous age that contain beds rich in organic carbon $\left(\mathrm{C}_{\text {org }}\right)$ have been recovered at many Deep Sea Drilling Project (DSDP) sites, particularly in the Atlantic Ocean. Most of these sequences display a marked cyclicity in amount of $\mathrm{C}_{\text {org }}$ resulting in interbedded lighter and darker shale, marlstone, and (or) limestone. Lower Cretaceous (Neocomian) $\mathrm{C}_{\text {org }}$-rich strata accur within carbonates, but most of the other Cretaceous strata in the Atlantic are carbonate-poor and clay-rich, resulting in cyclic interbedding of red, green, and black claystone or shale. In this chapter we use "black shale" to refer to darkcolored mudstone, but because we are dealing with

\footnotetext{
${ }^{1}$ Hay, W. W., Sibuet, J.-C., et al., Init. Repts. DSDP, 75: Washington (U.S. Govt. Printing Office).

2 Present address: Graduate School of Oceanography, University of Rhode Island, Narragansett, RI 02882.
}

freshly cut core material it is not always possible to tell if these mudstones would develop fissility on outcrop to make them "shale" in the classical sense.

Accumulation of $\mathrm{C}_{\text {org }}$-rich strata in the Atlantic began in the Early Cretaceous and has continued intermittently to the present. The interbedding of green and black, and green and red lithologies that is so common throughout the entire sedimentary sequence in the Atlantic Ocean is clearly a manifestation of varying diagenetic redox conditions within the sediments, but it is not clear whether fluctuations in amount of organic matter, that are related to sediment color, were caused by or were the cause of varying redox conditions in bottom waters just above the sediment/water interface. Nor is it clear to what extent deoxygenation of bottom waters overlying the sediments may have caused fluctuating redox conditions within the sediments.

Organic matter is preserved in relatively high concentrations in deep-sea $\mathrm{C}_{\text {org }}$-rich strata either because of 
high rate of supply of organic matter, enhanced preservation under anoxic conditions, enhanced preservation due to high sedimentation rate, or some combination of these factors. Once the organic matter reaches the sediment, some portion of it usually is decomposed, and various oxidizing agents are reduced in a series of oxidation/reduction reactions that are largely mediated by bacteria. The by-products of these reactions and of the decomposition of organic matter are various reduced metal species, ammonia, phosphate, sulfide, and large amounts of carbon dioxide and bicarbonate which contribute to increases in alkalinity in interstitial waters. Changes in the composition of organic matter with progressive diagenesis will not be considered in detail in this chapter, but the nature of the original organic matter and subsequent breakdown of organic compounds is extremely important in determining the ultimate chemistry and mineralogy of $\mathrm{C}_{\mathrm{org}}$-rich sediments because the amount and reactivity of organic matter in part controls the amount of oxidant that is reduced. In addition, organic matter may supply a large portion of trace metals found in $\mathrm{C}_{\text {org }}$-rich sediments, and, therefore, there may be a significant correlation between $\mathrm{C}_{\text {org }}$ content and concentrations of certain trace metals. Finally, the chemical nature of preserved organic matter is often used to draw inferences about the depositional environment (e.g., Didyk et al., 1978).

The purposes of this chapter are: (1) to outline the occurrence of $\mathrm{C}_{\mathrm{org}}$-rich facies of Cretaceous age at Site 530 and other DSDP sites in the North and South Atlantic, (2) to discuss the extent to which environment of deposition determines the supply of organic carbon to deeperwater sediments and therefore predetermines the extent to which diagenetic reactions and enrichment of certain trace elements can occur, and (3) to contrast the chemistry of $\mathrm{C}_{\mathrm{org}}$-rich facies from different depositional settings, and to briefly outline the potential effects of Cretaceous black-shale deposition and diagenesis on paleocean chemistry.

\section{ORGANIC-CARBON-RICH STRATA IN THE CRETACEOUS ATLANTIC OCEAN}

The oldest occurrences of $\mathrm{C}_{\text {org }}$-rich strata are within bioturbated white to light-gray limestone of Tithonian to Neocomian age recovered from DSDP Sites 101, 105, 367, 387, and 391 (Figs. 1 and 2A; Dean et al., 1978; Jansa et al., 1978 and 1979; Dean and Gardner, 1982). Upper Jurassic (Callovian-Oxfordian) strata containing as much as $3 \%$ organic carbon were recently recovered at DSDP Site 534 in the Blake-Bahama Basin (Sheridan, Gradstein, et al., 1982), but details of these strata are not yet available. The Neocomian laminated dark marlstone beds generally contain more than $5 \%$ organic carbon, and one bed at Site 367 in the Cape Verde Basin off northwest Africa contains 33\% organic carbon (Dean et al., 1978; Dean and Gardner, 1982).

The end of deposition of the Neocomian carbonates apparently was caused by a sudden rise in the carbonate compensation depth (CCD) (Arthur, 1979a; Thierstein, 1979), and the remainder of the section in the North Atlantic through the Eocene is dominated by multicolored clay-rich lithologies. At most DSDP sites in the North Atlantic, the Neocomian carbonates are overlain by the so-called middle Cretaceous (here defined as AptianAlbian to Turonian) black-shale facies, but at some sites the two are separated by a thin $(<10 \mathrm{~m})$ unit of interbedded red and green claystones of late Aptian to early Albian age (Jansa et al., 1978; Dean and Gardner, 1982).

The middle Cretaceous black-shale facies represents the main period of accumulation of organic matter in the Atlantic, and at most DSDP sites it consists of interbedded green and black clay-rich lithologies (see reviews by Arthur, 1979a; Tucholke and Vogt, 1979; Thierstein, 1979; Arthur and Natland, 1979; Tissot et al., 1979 and 1980; Dean and Gardner, 1982; Weissert, 1982). This facies has been recovered at DSDP Sites 4, 5, 101, 105, $135,137,138,144,367,368,369,370,386,387,391$, $398,400,402,415,416,417,418$ and 534 in the North Atlantic Ocean, and Sites 327, 328, 330, 356, 357, 361, $363,364,511$, and 530 in the South Atlantic Ocean (Fig. 1). Upper Jurassic (Oxfordian) black shale was recovered at Site 327 on the Falkland Plateau. This shale was deposited in shallow water and contains mostly terrestrial organic matter (McCoy and Zimmerman, 1977; Barker et al., 1977). Other than the Site 327 black shale, the main periods of black-shale deposition were during the Aptian-early Albian and sporadically from late Albian through Coniacian-Santonian (Arthur and Natland, 1979). The black-shale sequences are overlain by Upper Cretaceous red claystone. Concentrations of organic carbon in the black lithologies in the North Atlantic range from 3 to $37 \%$ and usually are more than $5 \%$ (Lancelot, Seibold, et al., 1978; Tissot et al., 1979 and 1980; Summerhayes, 1981; Dean and Gardner, 1982). Concentrations of organic carbon generally are lower in black lithologies from western North Atlantic sites than in those from eastern North Atlantic sites. True black shale usually amounts to less than half of the so-called black-shale facies.

The middle Cretaceous black-shale unit in the Cape Verde Basin (DSDP Site 367) is overlain by at least 160 $\mathrm{m}$ of interbedded green and brown clay of Late Cretaceous to late Paleocene/early Eocene age. The green and brown clay section is overlain by at least $85 \mathrm{~m}$ of interbedded green and black zeolitic, radiolarian clays of Eocene age; the black clay beds contain up to $4 \%$ organic carbon (Dean and Gardner, 1982). The Cretaceous/Tertiary red and green clays, like the Aptian/Albian red and green claystones, represent a period of accumulation of more-oxidized, $\mathrm{C}_{\text {org }}$-poor sediment sandwiched between strata deposited during periods of accumulation of less-oxidized, $\mathrm{C}_{\text {org }}$-rich sediment.

The organic detritus in $\mathrm{C}_{\text {org }}$-rich layers may be from autochthonous marine planktonic production, or from terrestrial organic debris. According to Tissot et al. (1979 and 1980), and Summerhayes (1981), autochthonous marine organic matter (that is, organic matter containing type II kerogen of Tissot et al. (1974) in continuous sections of Lower Cretaceous rocks in the North Atlantic is found only in the Cape Verde Basin (Site 367), on Cape Verde Rise (Site 368), and on Demerara 


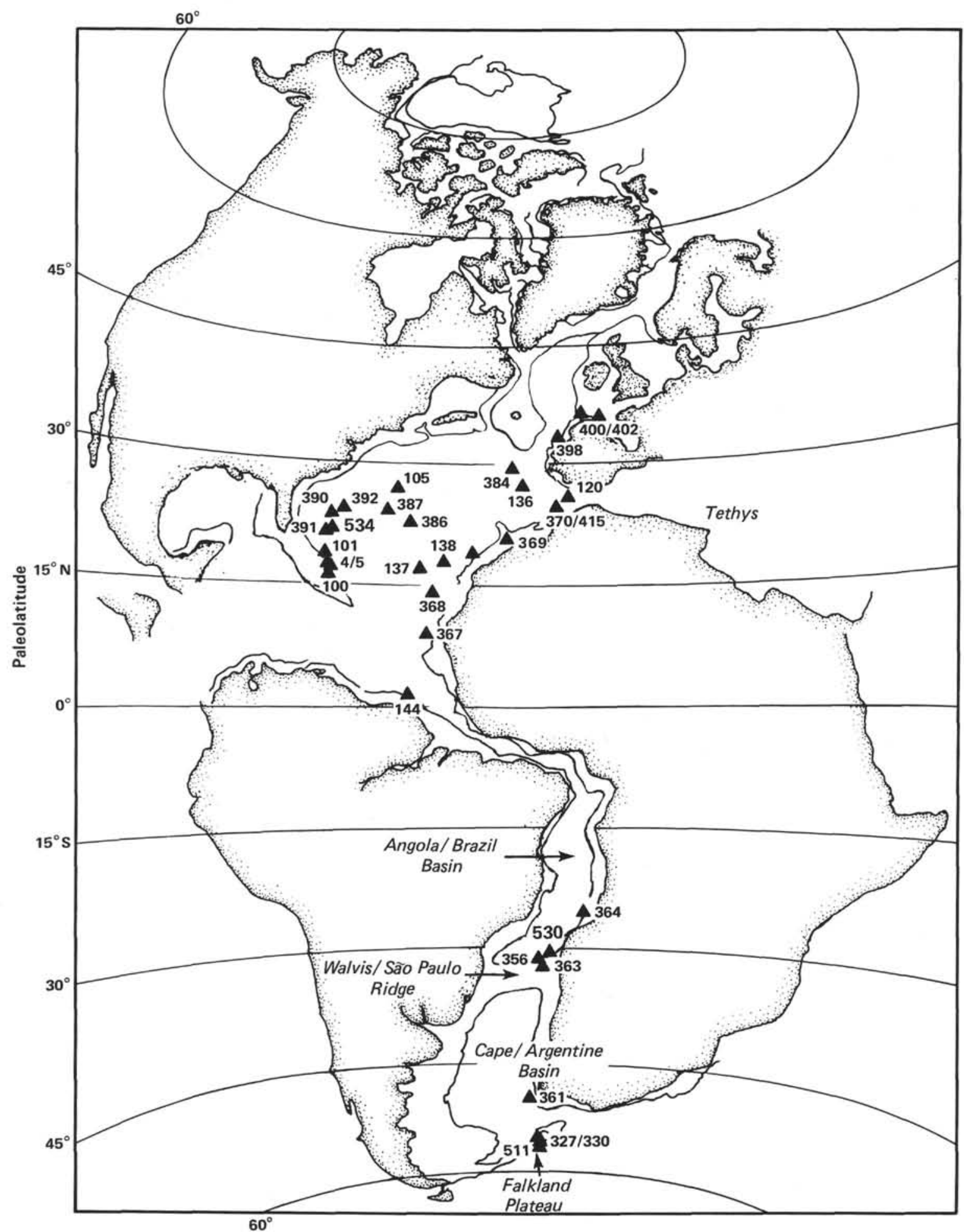

Figure 1. Map showing relative locations of DSDP sites where Lower and middle Cretaceous organic-carbon-rich strata have been recovered plotted on a continental reconstruction at $100 \pm 10$ m.y. ago. (Modified from Sclater et al., 1977.)

Rise (Site 144). Everywhere else in the North Atlantic, terrestrial organic matter with admixtures of highly degraded, residual marine organic matter dominates Lower Cretaceous $\mathrm{C}_{\text {org }}$-rich strata. The Cretaceous $\mathrm{C}_{\text {org }}$-rich strata in the southeastern North Atlantic, therefore, appear to have more in common with similar strata in the South Atlantic, where most of the organic matter is de- rived from marine sources, than with equivalent strata in the rest of the North Atlantic (Tissot et al., 1979 and 1980; Summerhayes, 1981).

In the South Atlantic sequences (Fig. 2B), organiccarbon concentrations average about 3 to $4 \%$ in the Aptian-lower Albian at Site 361 in the Cape Basin, with values as high as $14 \%$ (Arthur and Natland, 1979), and 

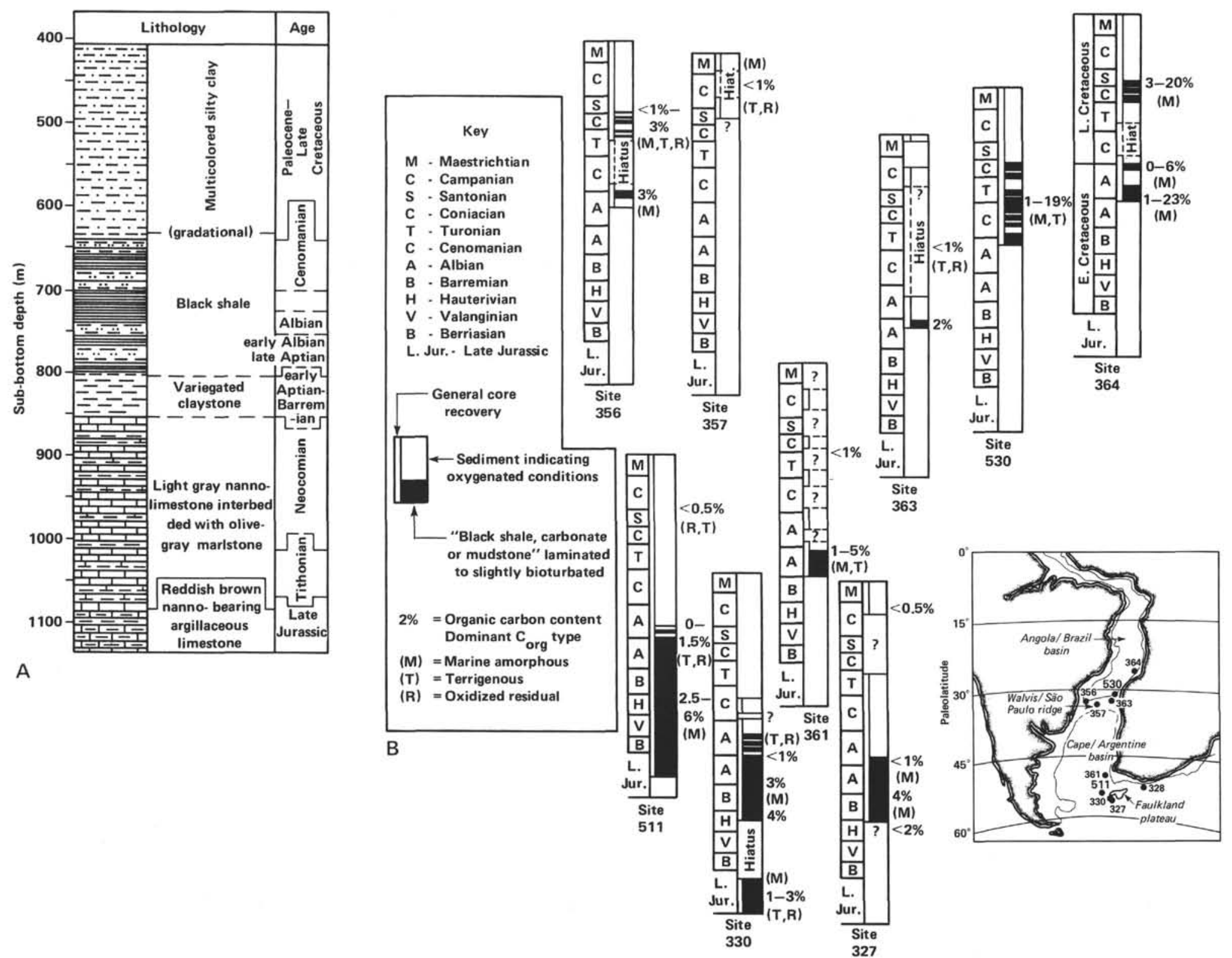

Figure 2. A. Summary stratigraphic column for Mesozoic strata recovered from DSDP sites in the North Atlantic Ocean. B. Summary stratigraphic columns for occurrences of Cretaceous $C_{\text {org }}$-rich strata at South Atlantic DSDP sites. Index map (inset) is modified from Sclater et al. (1977). 
5 to $7 \%$, with values as high as $24 \%$, in the lower Albian at Site 364 in the eastern Angola Basin. Average organic-carbon concentrations of 4 to $5 \%$ are typical of the Hauterivian-lower Aptian strata at Site 511 in the Argentine Basin (von der Dick et al., 1983), and less than $1 \%$ in the Aptian-Albian. The black-shale beds of Albian to Coniacian-Santonian age at Site $\mathbf{5 3 0}$ contain as much as $16.5 \%$ organic carbon with an overall average of $5.4 \%$ organic carbon as compared with less than $0.5 \%$ organic carbon in intercalated beds of red and green claystone (Meyers, Brassell, Huc, this volume). The black-shale beds occur within about $160 \mathrm{~m}$ of section but most are within $20 \mathrm{~m}$ of section in Cores 97 and 98 (Fig. 3). Most of the organic matter in black shales at Site $\mathbf{5 3 0}$ is of marine origin (Brassell et al., Deroo et al., this volume). The organic matter in black shales at Sites 364 and 511 also is mostly autochthonous marine organic matter (Tissot et al., 1980), whereas much of the organic matter at Site 361 in the Cape Basin apparently is redeposited terrestrial organic matter. In spite of these differences in sources of organic matter, the organic-carbon-rich strata in all Atlantic basins are interbedded with bioturbated, organic-carbon-poor strata.

The cyclic couplets of organic-carbon-rich and organic-carbon-poor beds are mainly several decimeters thick, but can range from several centimeters to as much as $80 \mathrm{~cm}$ thick. Periodicities of these cycles at most sites range from 20,000 to 100,000 years, with averages of about 40,000 to 50,000 years (Dean et al., 1978; Arthur and Fischer, 1977; Arthur, 1979a; McCave, 1979a). The thickness of an individual cycle depends mainly on sedimentation rate. For example, the average cycles in the Neocomian-Aptian carbonate facies are thicker than those in the more slowly deposited Aptian-Albian blackshale facies (Dean et al., 1978; Arthur, 1979a). Regardless of the exact mechanism involved in the formation of the sedimentary cycles, the pronounced cyclicity of the sedimentary section in the Atlantic, and particularly in the middle Cretaceous, suggests that there probably were cyclic variations in the influx of terrigenous organic matter and detrital material, sea-surface production of organic matter and $\mathrm{CaCO}_{3}$, dissolved oxygen concentration in deeper-water masses, and (or) preservation of $\mathrm{CaCO}_{3}$. The cyclicity of supply and (or) preservation of organic matter and $\mathrm{CaCO}_{3}$ had a pronounced influence on subsequent diagenetic events and on geochemical partitioning in adjacent beds.

\section{BLACK-SHALE DEPOSITION AT SITE 530}

The age of the oldest sediment above basaltic basement at Site 530 is late Albian-Cenomanian. The seafloor at Site 530 is presently at $4645 \mathrm{~m}$, and backtracking of the site using the methods of Sclater et al. (1977) and van Andel et al. (1977) gives an estimated paleodepth of about $2500 \mathrm{~m}$ during the Albian. This estimate is reasonable for the location of Site 530 at or near the ridge crest at that time. The site was several hundred kilometers from the African continental margin (Fig. 2), and at that time probably was separated from it by a trough. To the south, however, the site was flanked by the aseismic Walvis Ridge. There appears to have been a continuous paleoslope or steep scarp between the Walvis Ridge and the part of the Cretaceous mid-ocean ridge flank upon which Site $\mathbf{5 3 0}$ was located. There is a greater likelihood that any redeposited sediment at Site 530 was derived from the flank of Walvis Ridge than from the more distant African continental margin. This has implications for the origin of the $\mathrm{C}_{\text {org }}$-rich intervals in the mid-Cretaceous of Site 530.

Thin black shale beds are intercalated within green and red mudstone beds throughout the $165-\mathrm{m}$ interval (1105-940 m sub-bottom) from upper Albian to Coniacian-Santonian (Fig. 3). Black-shale beds make up 5 to $50 \%$ of the recovered section and occur as 260 thin beds $(<1$ to $62 \mathrm{~cm}$ with an average of $4.3 \mathrm{~cm}$ ). Very finegrained, thin-bedded turbidites make up between 5 and $20 \%$ of the section and occur both in the black shales and in the interbedded green and red mudstones. Organic carbon contents range from 1.4 to nearly $19 \%$ over the interval (Meyers, Brassell, and Huc, and Deroo et al., this volume) and Rock-Eval pyrolysis results suggest that most of the organic matter is marine in origin, at least in the more $\mathrm{C}_{\text {org }}$-rich intervals (Brassell, Deroo et al., Meyers, Brassell, and Huc, this volume). There is a good correlation between $\mathrm{C}_{\mathrm{org}}$ content and the kerogen hydrogen index (Fig. 4) suggesting that the degree of oxidation is the main control of hydrogen and oxygen indices of kerogen in Site 530 black-shale beds. All kerogen samples that have a hydrogen index greater than $100 \mathrm{mg} \mathrm{HC} / \mathrm{g} \mathrm{C}_{\text {org }}$ have low oxygen indices (less than $50 \mathrm{mg} \mathrm{O} / \mathrm{g} \mathrm{C}_{\text {org }}$ ), indicating good preservation of original autochthonous marine organic matter (Fig. 5). Sediment samples containing less than 2 to $3 \% \mathrm{C}_{\text {org }}$ have hydrogen indices of less than $200 \mathrm{mg} \mathrm{HC} / \mathrm{g} \mathrm{C}_{\text {org }}$ (Fig. 4). This suggests that there was a critical $\mathrm{C}_{\text {org }}$ content of about $3 \%$ at this site below which subsequent early diagenetic oxidation was deleterious, resulting in poor preservation. The high oxygen and low hydrogen indices therefore probably reflect mainly oxidation of marine organic matter rather than an increased flux of terrestrial higher plant debris, although there may be a background residual of terrestrial $\mathrm{C}_{\text {org }}$ as in Cretaceous black shales from sites in the North Atlantic (e.g., Summerhayes, 1981).

The excellent preservation of organic matter in certain thin beds within the Cretaceous multicolored claystone sequence (Unit 8 ) at Site 530 could have originated by one or more of the following mechanisms (e.g., Demaison and Moore, 1980; Muller and Suess, 1979): (1) periodic high productivity and high flux of $\mathrm{C}_{\mathrm{org}}$ to the deep-sea floor; (2) enhanced preservation under anoxic conditions; and (3) enhanced preservation under exceptionally high sedimentation rates. All three mechanisms have been called upon either singly or in combination by other authors to explain Cretaceous deepwater black shales at other DSDP sites. Depending upon paleolatitude, proximity to continental sources, and rates of circulation and oxygen content of deep-water masses, a different mechanism could satisfactorily explain enhanced preservation of $\mathrm{C}_{\text {org }}$ in each locality (e.g., Arthur and Natland, 1979; Dean et al., 1977; Summerhayes, 1981; Ibach, 1982). There is undoubt- 


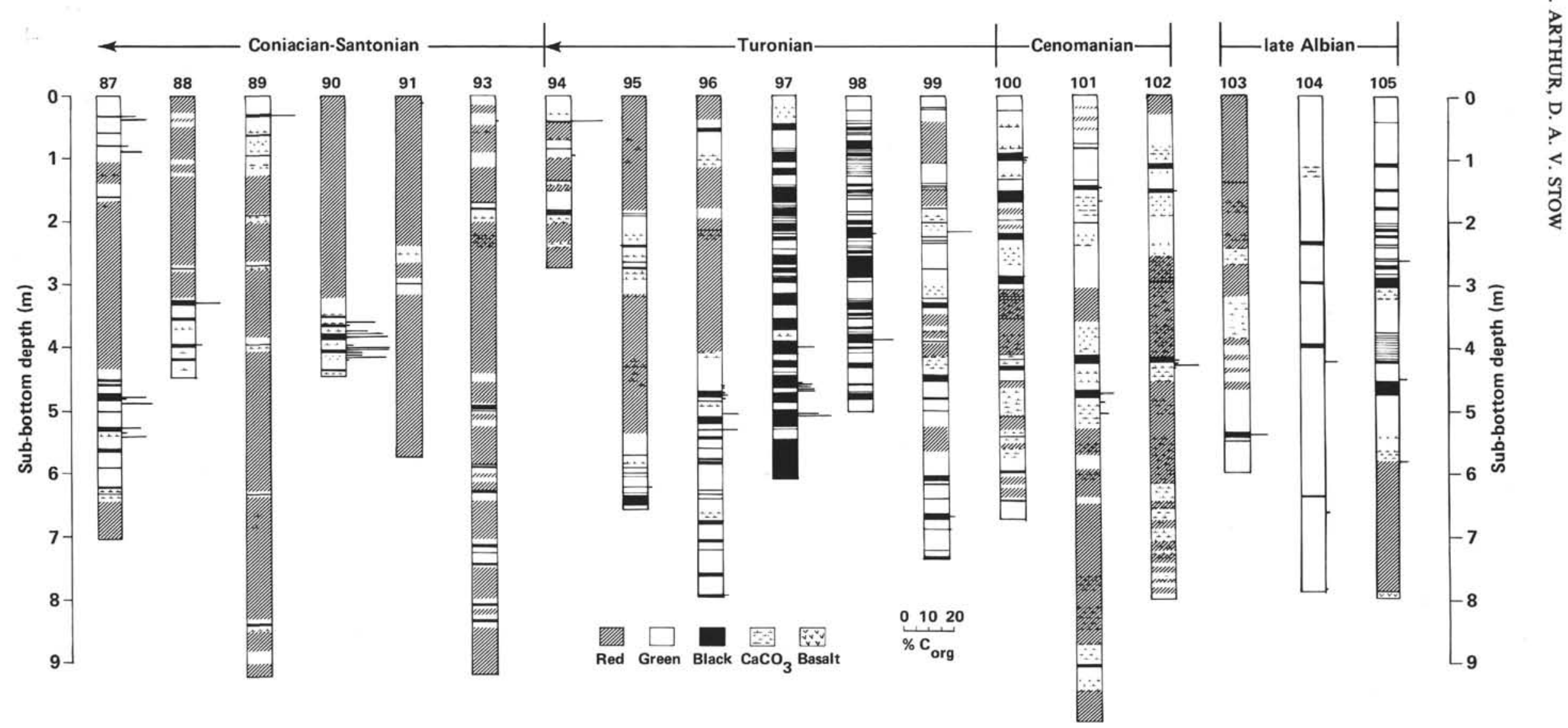

Figure 3. Summary stratigraphic columns of Cores 87-105 from Hole 530A showing the distribution of red and green claystone beds, black-shale beds, and $\mathrm{CaCO}_{3}$. 


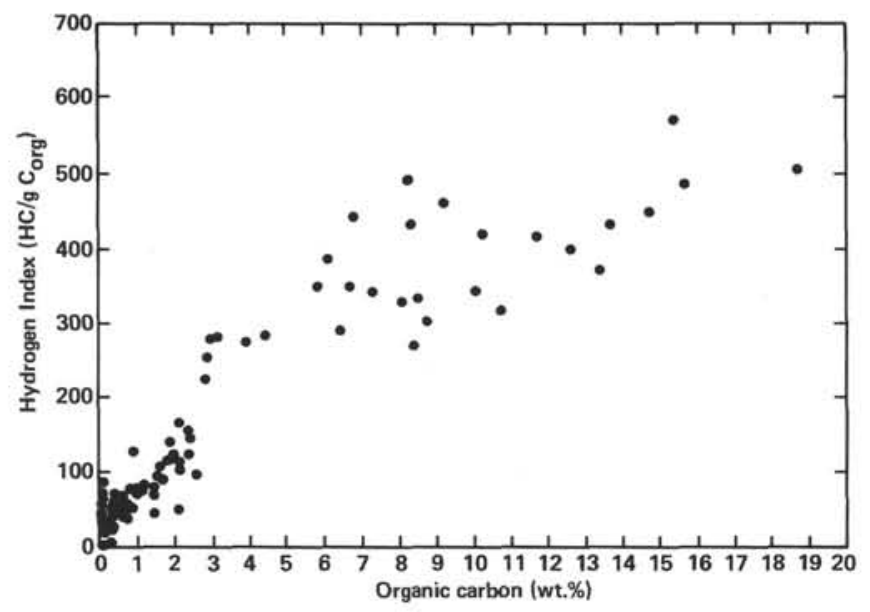

Figure 4. Scatter diagram of hydrogen index and percent $\mathrm{C}_{\text {org }}$ in red and green claystones and black shales in Hole 530A. Data from Deroo et al., this volume.

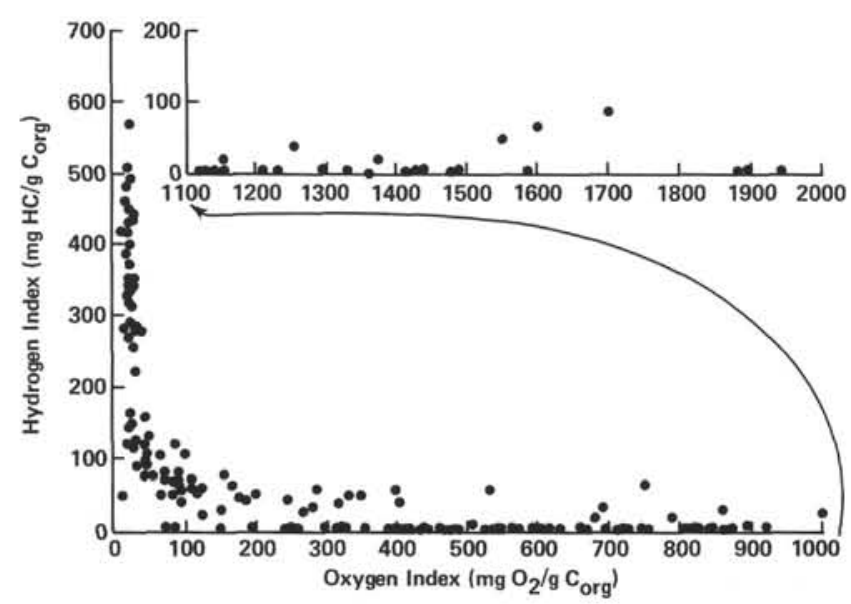

Figure 5. Scatter diagram of hydrogen and oxygen indices for organic matter in red and green claystones and black shales in Hole 530A. Data from Deroo et al., this volume.

edly a complex interplay between each of the three mechanisms. At Site 530, however, none of the three seems to have played a direct role in preservation of $\mathrm{C}_{\text {org }}$, although they all may have indirectly affected the accumulation of black clays there.

Evidence for exceptionally high productivity during deposition of mid-Cretaceous sediment at Site 530 is lacking. Although concentrations of $\mathrm{C}_{\text {org }}$ are high, they occur intermittently in discrete beds that commonly are separated by substantial thicknesses of red or green claystone. Except for Cores 97 and 98, black beds generally comprise less than $10 \%$ of the section (Fig. 3). Other evidence of high surface productivity, such as high concentrations of biogenic silica and phosphate, also is largely absent (see Dean and Parduhn, this volume). The argument that a high sedimentation rate also aids in the preservation of $\mathrm{C}_{\text {org }}$ does not directly apply to Site 530 black shale. Accumulation rates of $\mathrm{C}_{\mathrm{org}}$ are not particularly high (maximum of $46 \mathrm{~g} / \mathrm{cm}^{2} / \mathrm{m} . \mathrm{y}$.; Table 4) and are about one order of magnitude lower than average accumulation rates of $\mathrm{C}_{\text {org }}$ in other At- lantic black-shale sequences. Sedimentation rates vary from 9 to $14.6 \mathrm{~m} / \mathrm{m}$.y. at Site 530 , which are relatively low. The range of accumulation rates of $\mathrm{C}_{\text {org }}$ at Site 530 (Table 4), with an average of about $10 \mathrm{~g} / \mathrm{cm}^{2} / \mathrm{m} . \mathrm{y}$., are somewhat low relative to those reported by Müller and Suess (1979) and Ibach (1982). (The accumulation rates reported by Ibach are 100 times too high because of an error in her equation for computing total organic carbon accumulation rates.) At sedimentation rates of 9 to $14.6 \mathrm{~m} / \mathrm{m} . \mathrm{y}$., an average $\mathrm{C}_{\text {org }}$ accumulation rate of $10 \mathrm{~g} / \mathrm{cm}^{2} / \mathrm{m} . \mathrm{y}$. falls slightly below the typical "black clay" facies of Ibach (1982) but within her "'black claysiliceous overlay." However, when considered on an individual basis, the black shale beds contain an average of $5.4 \% \mathrm{C}_{\text {org }}$ (Meyers, Brassell, and Huc, this volume), but make up less than $10 \%$ of the total section. Interbedded red and green claystone layers contain no significant amount of $\mathrm{C}_{\text {org }}$. The black layers must be considered separately because they represent episodic sedimentation events and because they contain a disproportionate share of the $\mathrm{C}_{\text {org }}$ in the sequence.

We find it difficult to explain the interbedding and sedimentary structures in the multicolored claystone sequence using models that require periodic anoxia as a cause of the interbedding. The frequency of changes from oxic to anoxic conditions would have to have been highly variable, but with an average period of about 60,000 years (Table 4). Abrupt decreases in deeper-water oxygen content are unlikely, so that the black layers containing better preserved $\mathrm{C}_{\text {org }}$ should not have sharp basal contacts with underlying clay layers depleted in $\mathrm{C}_{\text {org }}$. Burrowing organisms should continue to mix sediment until deep-water oxygen contents reach about 0.5 ml/1 (e.g., Rhoads and Morse, 1971). Therefore, there should be a mottled transition zone between the underlying red or green clay and the black clay layer. Sharp upper contacts could occur as a result of abrupt oxygenation events, but subsequent burrowing activity would tend to disrupt upper contacts of black clay layers. Therefore, if the black clay layers represent episodes of anoxia at the seafloor, one would usually expect gradation in organic content, color, and lamination from underlying oxidized intervals into laminated black clays and to overlying oxidized sediment. About $80 \%$ of the black-shale beds at Site 530 are at least partly laminated (Stow and Dean, this volume). Some of this lamination is in the form of very thin silt laminae (Site 530 summary chapter; Stow and Dean, this volume). Many of these silt laminae clearly are parts of very thinbedded, fine-grained turbidites, and these turbidites occur within at least $25 \%$ of the black-shale beds. About $40 \%$ of the black-shale beds are bioturbated to some extent, although the burrows generally are smaller than in interbedded green mudstones. Much of the evidence for turbidites in the red and green mudstones has been obliterated by bioturbation. We suggest that the blackshale layers at Site 530 contain material that was redeposited from the flank of Walvis Ridge and represent a distal turbidite facies where the sediment source was predominantly within an intense oxygen-minimum zone. This could explain the high $\mathrm{C}_{\mathrm{org}}$ content of individual 
layers and the excellent preservation of autochthonous marine organic matter. Surface organic productivity may have been high in upwelling zones located along the southwest African continental margin (e.g., Parrish and Curtis, 1982) which led to an intense and relatively thick mid-water oxygen-minimum zone over much of the Angola Basin. Although productivity was not necessarily high along the seaward portions of the Walvis Ridge, organic matter was preserved along the ridge slope within the intensified oxygen-minimum zone. Frequent slumps and turbidity currents might have occurred because of high sedimentation rates, steep slopes, periodic earthquakes, and (or) intense gas generation in the $\mathrm{C}_{\text {org }}{ }^{-}$ rich slope sediments.

Redeposition of black clay to deeper water does not necessarily negate the hypothesis of "oceanic anoxic events"' (Schlanger and Jenkyns, 1976). The widespread, nearly synchronous deposition of $\mathrm{C}_{\text {org }}$-rich strata over much of the Atlantic and Tethys during, for example, the Aptian-Albian and the Cenomanian-Turonian argues for some fundamental difference between the oceans during these time periods and most of the Late Cretaceous-Cenozoic. At Site 530 we can see the imprint of such an oxygen-deficient event in the much greater frequency of black-shale interbeds near the Cenomanian/Turonian boundary. This record of maximum deposition of black shale occurs in Cores 97 and 98 (Fig. 3.) in which the accumulation rate of $\mathrm{C}_{\text {org }}$ is 4 to 10 times that of the rest of the sequence (Fig. 10; Table 4). We suggest that this culmination of black shale deposition reflects an increase in productivity near the southwest African margin, an expansion and intensification of the oxygen-minimum zone that impinged on Walvis Ridge, or both.

\section{GEOCHEMISTRY OF ORGANIC- CARBON-RICH STRATA}

\section{Sulfur}

Sulfur is incorporated into anoxic, organic-carbonrich sediments mainly through bacterial sulfate reduction. This process is relatively well known (e.g., Berner, 1971, 1974, 1978, 1980; Goldhaber and Kaplan, 1975 and 1980; Goldhaber et al., 1977; Jorgensen, 1977; Oremland and Taylor, 1978) and involves the utilization of pore-water sulfate as an electron donor for the oxidation of sedimentary organic matter by bacteria in the absence of dissolved molecular oxygen. Organic carbon is consumed in the proportion of two moles for every mole of sulfate reduced. Sulfate reduction usually proceeds after all other oxidants are consumed. For example, Froelich et al. (1979) found that for pelagic sediments in the eastern equatorial Atlantic, oxidants were consumed in the following order of decreasing energy produced per mole of organic carbon oxidized: $\mathrm{O}_{2}>$ Mn-oxides $>\mathrm{NO}_{3}^{-}>\mathrm{Fe}$-oxides $>\mathrm{SO}_{4}^{2-}$. And yet, in most anoxic sediments, sulfate accounts for most of the oxygen consumption and organic-matter decomposition. For example, Jorgensen (1977) found that sulfate reduction accounted for $53 \%$ of the mineralization of organic matter in anoxic sediments of a fjord in Denmark. Jorgensen also found that only $10 \%$ of the sulfide produced by sulfate reduction was precipitated as metal sulfides and the rest diffused to the surface where it was reoxidized. Berner (1978) suggested than an average of 0.2 to 0.4 weight percent of the organic carbon is lost from sediments during sulfate reduction, but this amount may vary depending upon the rate of sedimentation and the amount of sulfate available by diffusion into the sediment, as well as on the type and reactivity of organic matter present (Toth and Lerman, 1977; Berner, 1980; Goldhaber and Kaplan, 1980). The reduced sulfur is free to diffuse upward to the sediment-water interface, where it can be oxidized by bacteria, or to diffuse to sites of metal-sulfide precipitation, a major sink for sulfur in anoxic sediments. Modern anoxic sediments contain concentrations of total sulfur of up to several weight percent. The weight ratio of sulfur to organic carbon in modern anoxic sediments averages 0.4 , but there are significant variations from this value. Levanthal (1983) suggested, based on data for S:C ratios from the Black Sea that S:C ratios greater than 0.4 in black shales, with a slope intersect at a positive value of sulfur at zero carbon, signify deposition under an anoxic water column, rather than having only anoxic sediment pore waters. Sulfur in excess of that diffusing into sediments from overlying seawater is presumably added to sediment by sulfate reduction and formation of metal sulfides in the overlying anoxic water column.

Figure 6 is a plot of organic carbon versus sulfur for those samples of Cretaceous strata for which both organic-carbon and sulfur analyses are available. This plot suggests that a $\mathrm{S}: \mathrm{C}$ ratio of about 0.4 is a reasonable average for these strata, which is similar to the $\mathrm{S}: \mathrm{C}$ ratio in most modern anoxic sediments. Kendrick (1979; data included in Fig. 6) measured concentrations of total sulfur of up to 4.3 weight percent in organic-carbon-rich strata from DSDP Sites 386 and 387. As much as $40 \%$ of this sulfur apparently is in the organic fraction, and the rest in pyrite. Kendrick interpreted this sulfur enrichment as evidence for deposition and preservation of organic carbon under an anoxic water column. Low concentrations of sand organic carbon were interpreted as an indication of oxic bottom-water conditions.

Metal sulfides of varying morphologies are present in nearly all of the Cretaceous organic-carbon-rich strata recovered from DSDP sites in the Atlantic. Pyrite is the most commonly reported sulfide mineral and occurs as framboids, test-fillings of foraminifers, micronodules, replacements or molds of radiolarian tests, and large discrete nodules and lenses. Localized concentrations of pyrite and (or) marcasite are commonly observed at contacts between black shale and underlying green claystone beds (Fig. 7). In fact, sulfide sulfur appears to be very mobile in sequences of interbedded organic-carbon-rich and organic-carbon-poor strata (Berner, 1969 and 1970), and green claystone beds often contain as much total sulfur as adjacent beds of black shale.

Sedimentation rates were generally high, and burrowing apparently was sufficiently ineffective during de- 


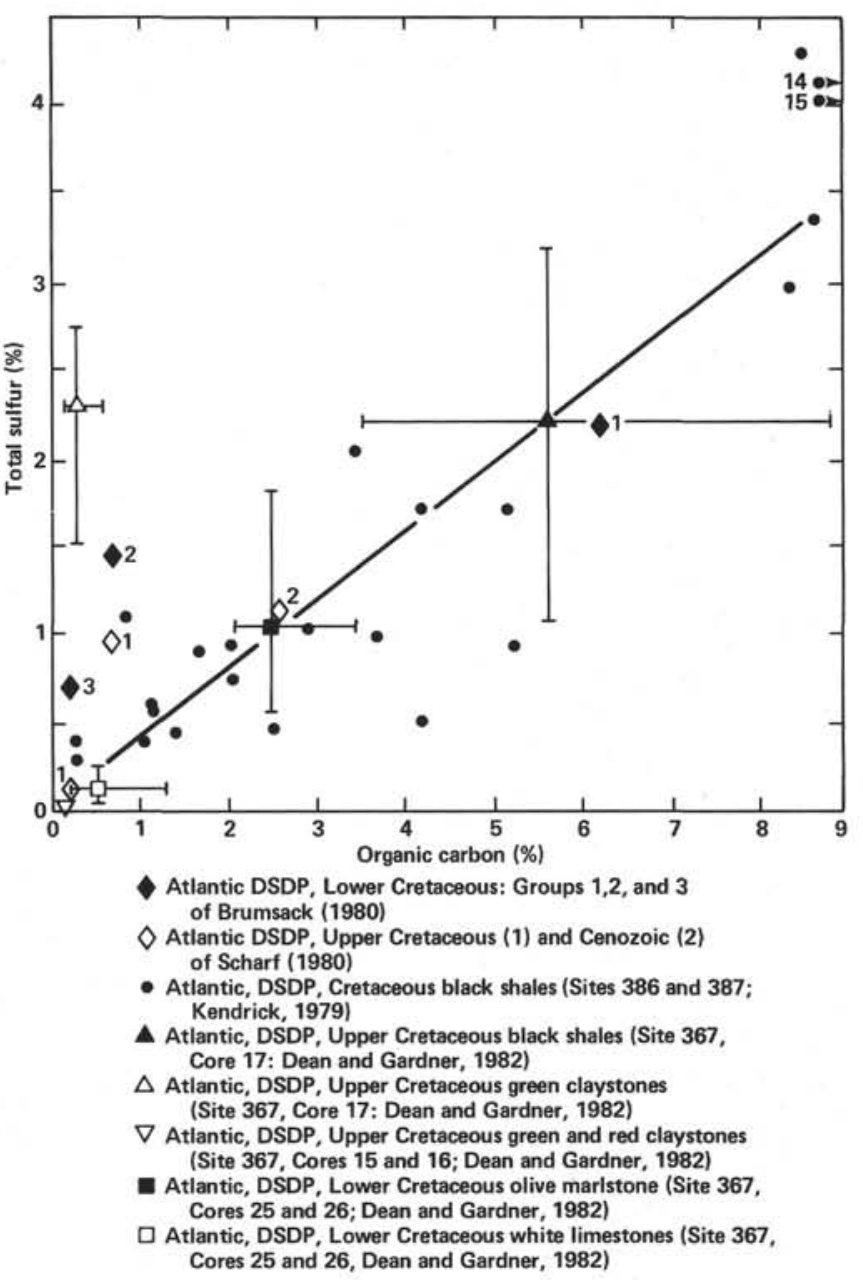

Figure 6. Plot of concentrations of organic carbon and total sulfur (presumably as sulfide sulfur) in Cretaceous organic-carbon-rich strata from Atlantic DSDP sites. Although there is a large amount of scatter, the slope of a regression line through the data is about 0.4 , similar to that for plots of organic carbon versus total sulfur in modern anoxic Black Sea sediments (Leventhal, 1983).

position of organic-carbon-rich strata in many Cretaceous deep-sea environments to inhibit extensive diffusion of sulfate into the sediment. Availability of ferrous iron probably was never a limiting factor in metal sulfide formation in Cretaceous $\mathrm{C}_{\text {org }}$-rich strata.

\section{Phosphate}

Atlantic Cretaceous $\mathrm{C}_{\text {org }}$-rich strata usually have a large range of phosphorus concentrations $(0.005$ to 1.8 weight percent $\mathrm{P}_{2} \mathrm{O}_{5}$ ), but we know of no reported phosphate-mineral aggregates, such as pellets or nodules, from these strata. Most phosphorus is supplied to sediments in productive areas of the oceans in organic matter and fish debris (Froelich et al., 1982). Phosphate is released from organic matter by decomposition both in the water column during settling of organic matter and fecal pellets to the bottom, and in sediment pore waters during aerobic and anaerobic decomposition (e.g., Froelich et al., 1979). The C:P ratio in organic matter increases systematically as organic matter settles through the water column and during early diagenesis (Suess,

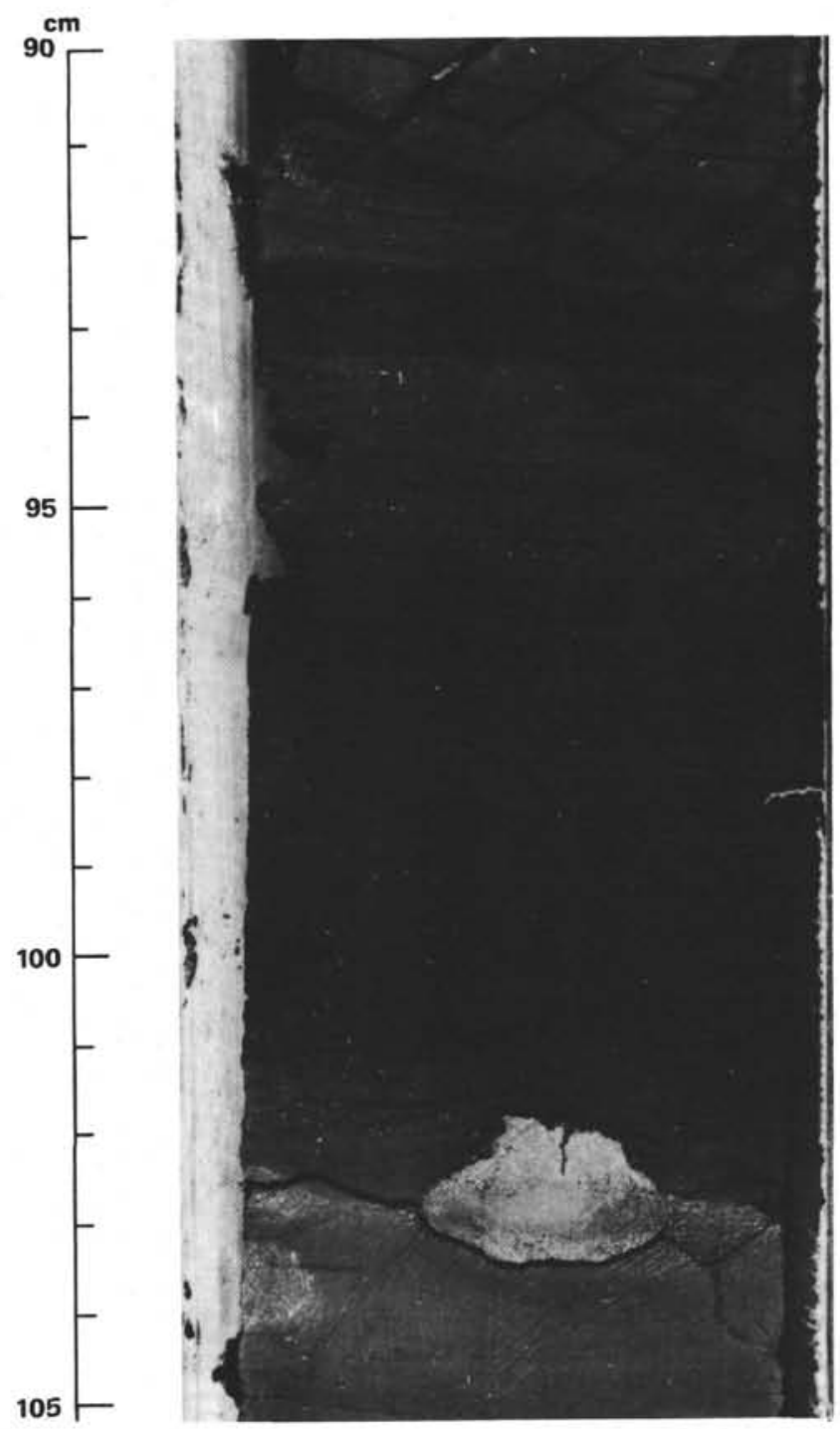

Figure 7. Pyrite nodule at the contact between a bed of black shale and an underlying bed of green claystone: Sample 530A-104-3, 90-105 $\mathrm{cm}$.

1980; Froelich et al., 1982). As organic matter decomposes in the sediment, phosphate is liberated to pore waters; it can diffuse out of the sediment into overlying seawater and (or) precipitate in sediment as some phosphatic phase, or by adsorption on Fe-oxyhydroxides at an oxic/anoxic interface (e.g., Berner, 1974; Curtis, 1980). In general, dissolved phosphate in pore waters of organic-carbon-rich sediments increases with depth to a maximum that may be controlled by precipitation of a carbonate-fluorapatite phase (e.g., Baturin et al., 1970; Berner, 1980; Suess, 1981) due to decomposition of organic matter and possibly through dissolution of fish debris (Suess, 1981). Fish debris usually is well preserved in organic-carbon-rich strata, suggesting that dissolution is buffered by the increases in phosphate concentrations due to decomposition of organic matter. Baturin et al. (1970) found maximum phosphate concentrations of $9.7 \mu \mathrm{g}$-at $/ 1$ in pore waters of Walvis Bay muds, over three times the highest concentration in open oceanic 
deep waters. Concentrations of phosphate several orders of magnitude higher than those in overlying seawater have been reported from sediments in nearshore environments (Baturin, 1972; Nissenbaum et al., 1972; Sholkovitz, 1973; Berner, 1974; Suess, 1976). A limit to the amount of phosphate that can be buried in sediment is the initial C:P ratio in the sedimenting organic matter. Deep-water organic-carbon-rich sediments may not be a major sink for phosphorus because, although much organic matter may be preserved in anoxic strata, much of the organic phosphorus may have been liberated to deep-water masses by decay of organic matter settling to the bottom. Thus, the C:P ratio of sedimented organic matter may already be elevated, and the total phosphorus content of deeper-water organic-carbonrich sediments will be relatively low (Glenn and Arthur, 1982). The average $\mathrm{P}_{2} \mathrm{O}_{5}$ content of modern organiccarbon-rich sediments from the Black Sea is 0.17 weight percent, which is similar to or lower than concentrations in oxic sediments where phosphate is adsorbed onto ferric oxyhydroxides (Berner, 1974). Analyses of Cretaceous deep-water organic-carbon-rich strata and interbedded organic-carbon-poor strata show that average $\mathrm{P}_{2} \mathrm{O}_{5}$ values are generally below 0.18 weight percent in Atlantic DSDP sites (e.g., Sites 105, 364, 386, 387, $417 \mathrm{D}$, and 530), with a range of 0.06 to 1.77 weight percent. The few available analyses from DSDP Site 369 on the northwest African continental slope (Donnelly, 1980) suggest that organic-carbon-rich Cretaceous nannofossil marl and limestone at that site have concentrations of $\mathrm{P}_{2} \mathrm{O}_{5}$ that are higher than deeper-water strata of equivalent age. Phosphate probably occurs mainly in the form of preserved phosphatic fish debris in most deep-sea organic-carbon-rich strata.

The geometric mean concentration of $\mathrm{P}_{2} \mathrm{O}_{5}$ in black shale from Site 530 is 0.18 percent (Dean and Parduhn, this volume). The average concentration of organic carbon in all samples of black shale reported by Meyers, Brassell, and Huc (this volume) is $5.4 \%$. These two average values yield an average $C: P$ atomic ratio of 168 which is relatively high (compare with 106 , the average Redfield ratio in freshly fixed planktonic organic matter; Redfield, 1958). Phosphorus accumulated at rates between 0.013 and $0.58 \mathrm{~g} / \mathrm{cm}^{2} / \mathrm{m} . y$. (average of about 0.2 ) in the black shales at Site 530, which are not exceptionally high values.

\section{Trace Elements}

The Cretaceous $\mathrm{C}_{\text {org }}$-rich strata in the Atlantic provide insight into the general problem of incorporation of trace metals in organic-carbon-rich sediments. Such marine sediments and rocks are known to be significantly enriched in a variety of redox-sensitive trace elements (e.g., Vine and Tourtelot, 1970) relative to average marine sediment and shale, but the degree of enrichment varies greatly. Few systematic studies have been made of major- and trace-element concentrations in Cretaceous deep-sea organic-carbon-rich lithologies, but such studies are important because these relatively thick and laterally extensive lithologic units are potential sinks for organic carbon, sulfur, and trace elements, particularly As, $\mathrm{Ba}, \mathrm{Cd}, \mathrm{Co}, \mathrm{Cr}, \mathrm{Cu}, \mathrm{Mo}, \mathrm{Ni}, \mathrm{Pb}, \mathrm{V}$, and $\mathrm{Zn}$. During the deposition of organic-carbon-rich sediments, it is possible that trace elements, organic carbon, and sulfur are extracted from the oceans at greater than steady-state rates, thereby perturbing the chemical and isotopic balances of the ocean. The possible effects of Cretaceous black-shale deposition on the global carbon cycle has been discussed by Scholle and Arthur (1980) and Arthur (1982). These authors found that average $\delta^{13} \mathrm{C}$ values of oceanic total dissolved carbon increased during midCretaceous black-shale deposition, as did the rates of accumulation of organic carbon in the deep sea. Average deep-sea accumulation rates of organic carbon were as much as seven times those of today during the peak of Aptian-Albian black-shale deposition. The reasons for the enhanced preservation of organic carbon in the Cretaceous deep sea basins, however, are still a matter of debate (see discussion below). Anderson et al. (1982) suggested that increased rates of burial of sulfur as metal sulfides in Cretaceous black shales caused significant changes in the oceanic sulfur cycle. Brumsack (1980) also considered the possible effects of Cretaceous blackshale deposition on trace-metal and carbon cycling, but his estimates of the fluxes of those components to the black shales probably are too high because he considered the entire thickness of a so-called "black shale" unit to have the composition of his "average" black shale (see Tables 1 and 2). As we have already pointed out, black-shale-bearing units recovered from Atlantic DSDP sites commonly contain less than 10 to $20 \%$ of beds with an organic-carbon concentration of more than $1 \%$, but some intervals have higher proportions. In this section, we contrast the geochemistry of interbedded black, green, and red Cretaceous strata, and compare their geochemistry and metal accumulation rates with those of modern anoxic sediments.

The enrichment of certain trace elements-especially $\mathrm{Cu}, \mathrm{Zn}, \mathrm{Mo}, \mathrm{V}, \mathrm{Ni}$, and $\mathrm{Cr}$-in sediments and rocks enriched in organic matter has been reported by many investigators (e.g., Wedepohl, 1964; Brongersma-Sanders, 1965; Calvert and Price, 1970; Vine and Tourtelot, 1969 and 1970; Volkov and Fomina, 1974; Lange et al., 1978; Brongersma-Sanders et al., 1980; Dean and Gardner, 1982; Dean and Parduhn, this volume). The association of high trace-element concentrations with organic matter may be the result of concentration of these elements by organisms (bioconcentration), by chemical sorption and precipitation with organic detritus, clays, etc. settling through the water, or by formation of sulfides under anoxic conditions created by a flux of excess organic carbon. Marine plankton are known to concentrate trace elements, especially $\mathrm{Ba}, \mathrm{Pb}, \mathrm{Ni}, \mathrm{Cu}, \mathrm{Zn}, \mathrm{Mn}$, and $\mathrm{Fe}$ (Vinogradov, 1953; Goldberg, 1957; Boyle and Lynch, 1968; Knauer and Martin, 1973; Martin and Knauer, 1973; Vinogradova and Kovalskiy, 1962; Bostrom et al., 1974; Chester et al., 1978; Moore and Bostrom, 1978; Leinen and Stakes, 1979), and this suggests that bioconcentration is a potentially important mechanism for incorporation of certain trace elements in organic-carbonrich marine sediments. However, the great effectiveness 
Table 1. Average or representative chemical analyses for modern organic-carbon-rich sediments, oxic deep-sea sediments, and Cretaceous black shales and interbedded strata.

\begin{tabular}{|c|c|c|c|c|c|c|c|c|c|c|c|c|c|c|c|c|}
\hline \multirow{2}{*}{\multicolumn{2}{|c|}{$\frac{\text { Component } \quad \text { Black }}{\text { Oxide or Element }(\%)}$}} & $\mathrm{Sea}^{\mathrm{a}}$ & \multicolumn{2}{|c|}{$\begin{array}{l}\text { Bunnefjord } \\
\text { Norway }\end{array}$} & \multirow{2}{*}{$\begin{array}{l}\text { Mean of } \\
52 \text { anoxjc } \\
\text { samples }\end{array}$} & \multirow[t]{2}{*}{$\begin{array}{l}\text { Mean of } \\
65 \text { oxic } \\
\text { samples }\end{array}$} & \multicolumn{2}{|c|}{$\begin{array}{l}\text { Walvis Bay } \\
\text { diatom } \\
\text { clay }^{\mathrm{c}}\end{array}$} & \multicolumn{2}{|c|}{ Baltic Sea ${ }^{d}$} & \multirow[t]{2}{*}{$\begin{array}{l}\text { Deep-sea } \\
\text { pelagic } \\
\text { clay }^{\mathrm{e}}\end{array}$} & \multicolumn{2}{|c|}{$\begin{array}{c}\text { Cretaceous } \\
\text { black shales } \\
\text { from Atlantic }\end{array}$} & \multicolumn{2}{|c|}{$\begin{array}{c}\text { Cretaceous } \\
\text { black shales } \\
\text { Site } 530^{8}\end{array}$} & \multirow[t]{2}{*}{$\begin{array}{l}\text { Cretaceous } \\
\text { red claystone, } \\
\text { Site } 530^{8}\end{array}$} \\
\hline & & & & & & & & & & & & & & & & \\
\hline $\mathrm{SiO}_{2}$ & 32.5 & $(51.8)$ & 34.9 & $(40.4)$ & & & 51.2 & $(57.6)$ & 39.0 & $(42.0)$ & 60.4 & & & 56.7 & [57.3] & 58.2 \\
\hline $\mathrm{Al}_{2} \mathrm{O}_{3}$ & 8.97 & $(14.3)$ & 8.77 & (10.1) & & & 2.92 & (3.28) & 14.2 & (15.3) & 19.1 & & & 11.8 & [11.9] & 12.6 \\
\hline $\mathrm{TiO}_{2}$ & 0.29 & $(0.46)$ & 0.43 & $(0.50)$ & & & 0.23 & $(0.26)$ & 0.72 & $(0.77)$ & 0.92 & & & 1.11 & {$[1.12]$} & 1.23 \\
\hline $\mathrm{Fe}_{2} \mathrm{O}_{3}$ & 4.82 & $(7.69)$ & 10.4 & $(12.1)$ & & & 1.62 & $(1.82)$ & 7.7 & $(8.3)$ & 8.93 & & & 8.5 & [8.61] & 10.0 \\
\hline $\mathrm{CaO}^{\circ}$ & 20.9 & & 7.3 & & & & 7.26 & & 2.2 & & & & & & & \\
\hline $\mathrm{MgO}$ & 2.21 & (3.53) & 1.83 & $(2.10)$ & & & 1.33 & $(1.49)$ & 2.7 & (2.9) & 3.73 & & & 2.8 & {$[2.8]$} & 3.3 \\
\hline $\mathrm{Na}_{2} \mathrm{O}$ & 1.61 & (2.57) & 0.93 & (1.08) & & & & & 0.3 & (0.3) & 1.67 & & & 1.39 & {$[1.40]$} & 1.46 \\
\hline $\mathrm{K}_{2} \mathrm{O}$ & 1.72 & (2.75) & 2.27 & (2.63) & & & 0.71 & $(0.80)$ & 4.3 & $(4.6)$ & 3.56 & & & 3.17 & {$[3.19]$} & 3.43 \\
\hline $\mathrm{MnO}$ & 0.066 & $(0.11)$ & 4.78 & (5.54) & & & & & 5.2 & (5.6) & 0.52 & & & 0.07 & {$[0.08]$} & 0.11 \\
\hline $\mathrm{P}_{2} \mathrm{O}_{5}$ & 0.27 & $(0.43)$ & 0.61 & $(0.71)$ & & & 1.59 & $(1.79)$ & 0.23 & $(0.25)$ & 0.16 & & & 0.18 & {$[0.19]$} & 0.17 \\
\hline $\mathrm{S}$ & 2.90 & & 4.26 & & & & 1.59 & & 2.8 & & & 2.19 & & & & \\
\hline $\mathrm{C}_{\text {org }}$ & 2.25 & & 5.44 & & & & 9.35 & & 4.6 & & & 6.18 & & & & \\
\hline \multicolumn{17}{|c|}{ Element (ppm) } \\
\hline As & & & 71 & (82) & 32 & 26 & & & & & 13 & & & 32 & [48] & \\
\hline $\mathrm{Ba}$ & 265 & (423) & 552 & (640) & 735 & 768 & 198 & (222) & 750 & (806) & 2300 & 530 & & 660 & [1111] & 830 \\
\hline $\mathrm{Cd}$ & & & & & & & & & & & 0.21 & 0.92 & & 8 & [28] & \\
\hline Co & 27 & (49) & 60 & (70) & 27 & 24 & & & 22 & (24) & 74 & 27 & (38) & 59 & [69] & 33 \\
\hline $\mathrm{Cr}$ & 107 & (171) & 107 & (124) & 125 & 113 & & & 90 & (97) & 90 & 202 & (257) & 180 & [222] & 112 \\
\hline $\mathrm{Cu}$ & 45 & (72) & 135 & (157) & 133 & 54 & 68 & (76) & 78 & (84) & 250 & 156 & (194) & 150 & [171] & 73 \\
\hline Mo & 26 & (42) & 26 & (30) & 33 & 33 & 53 & $(60)$ & 35 & (38) & 27 & 59 & (84) & 26 & [26] & \\
\hline $\mathrm{Ni}$ & 108 & (172) & 45 & (52) & 55 & 55 & 108 & (121) & 43 & (46) & 225 & 186 & (263) & 130 & [181] & 77 \\
\hline $\mathrm{Pb}$ & 10 & (16) & 167 & (194) & 148 & 148 & 12 & (13) & 25 & (27) & 80 & 16 & (21) & 27 & {$[27]$} & \\
\hline v & 188 & (316) & 276 & (320) & 181 & 181 & & & 130 & (140) & 120 & 822 & (1281) & 460 & [692] & 210 \\
\hline $\mathrm{Zn}$ & 76 & (121) & 944 & (1094) & 571 & 571 & 68 & (76) & 110 & (118) & 165 & 828 & (1207) & 320 & [782] & 110 \\
\hline
\end{tabular}

Note: All values in parentheses are recalculated on a carbonate-free basis.

b Analysis of organic-carbon-rich anoxic sediment in Bunnefjord, Norway; Doff (1969), quoted in Calvert (1976).

c Average of diatomaceous clay. Walvis Bay Southwest Africa; data of Calvert (1976).

d Average of diatomaceous clay, Walvis Bay Southwest Africa; data of

e Analysis of Gotland Basin anoxic sediment; data of Manheim (1961).

e Average of typical oxidized, deep-sea pelagic clay samples; data of Chester and Aston (1976).

Average of 38 samples of Atlantic black shales; data of Brumsack, 1980.

8 Geometric-mean concentrations of 28 samples of black shale, and 12 samples of red claystone from DSDP Site 530 . Values in brackets are arithmetic-mean concentrations for the black-shale samples. All values are on a carbonate-free basis. Data of Dean and Parduhn (this volume).

Table 2. Selected mean and range of concentration of trace elements in modern anoxic sediments and Atlantic Cretaceous "black shales" and associated strata.

\begin{tabular}{|c|c|c|c|c|c|c|c|c|c|c|c|}
\hline \multirow{3}{*}{$\frac{\text { Element }}{\text { As }}$} & \multicolumn{2}{|c|}{ Black Sea $^{a}$} & \multicolumn{3}{|c|}{$\begin{array}{l}\text { Green mud } \\
\text { Walvis Bayb }\end{array}$} & \multicolumn{3}{|c|}{$\begin{array}{c}\text { Cretaceous } \\
\text { black shales } \\
\text { DSDP Site } 530^{\mathrm{c}}\end{array}$} & \multicolumn{3}{|c|}{$\begin{array}{c}\text { Cretaceous } \\
\text { black shales } \\
\text { North Atlantic }\end{array}$} \\
\hline & \multirow{2}{*}{$\frac{\text { Mean }}{-}$} & \multirow{2}{*}{$\begin{array}{c}\text { Range } \\
-\end{array}$} & \multicolumn{2}{|c|}{ Mean } & \multirow{2}{*}{ Range } & \multicolumn{2}{|c|}{ Mean } & \multirow{2}{*}{$\begin{array}{r}\text { Range } \\
<20-92\end{array}$} & \multicolumn{2}{|c|}{ Mean } & \multirow{2}{*}{$\frac{\text { Maximum }}{-}$} \\
\hline & & & - & & & 32 & (48) & & - & & \\
\hline $\mathrm{Ba}$ & 327 & $92-1594$ & 440 & (198) & $1-3660$ & 660 & (1110) & $270-4400$ & 530 & & - \\
\hline Cd & - & - & - & & $1-79$ & 8 & (28) & $<6-114$ & 0.92 & & - \\
\hline Co & 26 & $11-46$ & - & & $1-7.7$ & 59 & (69) & $13-180$ & 27 & (38) & 94 \\
\hline $\mathrm{Cr}$ & 143 & $1-413$ & - & & $1-216$ & 180 & (222) & $57-570$ & 202 & (257) & 430 \\
\hline $\mathrm{Cu}$ & 38 & $1-214$ & - & & - & 150 & (171) & $75-430$ & 156 & (194) & 635 \\
\hline Mo & 13 & $1-188$ & 14 & (53) & $1-104$ & 26 & (26) & $<5-190$ & 59 & (84) & 606 \\
\hline $\mathrm{Ni}$ & 82 & $24-265$ & 30 & (108) & $1-166$ & 130 & (181) & $40-660$ & 186 & (263) & 870 \\
\hline $\mathrm{Pb}$ & 12 & $1-33$ & - & & - & 27 & (27) & $<20-100$ & 16 & (21) & 46 \\
\hline v & 225 & $144-463$ & - & & - & 460 & (692) & $120-2200$ & 822 & (1281) & 3627 \\
\hline $\mathrm{Zn}$ & 98 & $39-150$ & - & & $12-83$ & 320 & (780) & $68-5900$ & 828 & (1207) & 7158 \\
\hline
\end{tabular}

Note: All values are in parts per million (ppm) in bulk sample, and not on a carbonatefree basis, unless otherwise noted.

a Average of all Black Sea sediment analyses in 11 cores. Data from Hirst (1974).

b Mean concentrations are from Baturin and others (1970 and 1972) and Calvert and Price (1970) or Price and Calvert (1977; in parentheses). Concentration ranges are from Brongersma-Sanders et al. (1980).

c Geometric mean and range on a carbonate-free basis of concentrations of elements in 28 samples of black shale (from Dean and Parduhn, this volume). Values in parentheses are arithmetic means for comparison with other mean values in this table.

${ }^{d}$ Mean and maximum concentrations of elements in 38 samples of black shale containing more than $1.0 \%$ organic carbon (Brumsack, 1980). Mean values in parentheses are on a carbonate-free basis.

of absorption of trace metals by clay minerals and organic matter, and coprecipitation of trace metals, particularly as sulfide minerals, suggests that these processes also may play an important role in the removal of trace metals from seawater (Tourtelot, 1964 and 1979; Volkov and Fomina, 1974; Holland, 1979).

Tourtelot (1964) studied the minor-element compositions of contemporaneous Upper Cretaceous marine and nonmarine shales in the western interior of the United States and found that element concentrations were consistently higher in the marine shales. He concluded from this observation that sorption and syngenetic mineral formation in the marine environment were an important, if not the most important, processes affecting the minor-element content of shales. The final minor-element composition is thus the result of cycles of sorption-desorption and (or) precipitation-dissolution as the sediments are subjected to varying chemical conditions in depositional and diagenetic environments. The greatest control is probably exerted by redox condi- 
tions during diagenesis. Vine and Tourtelot (1970) also concluded that sorption processes are important in metal enrichment in black shales, but felt that some prior concentration of metals from seawater (for example, by bioconcentration) was required. They stated that the availability of metals in the various solutions that the organic matter comes in contact with throughout its history is probably the most significant factor in determining metal enrichment, and that interstitial pore fluids are probably the most important of these solutions.

If thin beds of black shale are interstratified with other lithologies, these beds may become sinks for elements mobilized and transported in pore waters during compaction (Berner, 1969 and 1975). The importance of interbedded more-reduced and less-reduced strata on the migration and accumulation of trace elements, and the relative mobility of different elements under reducing conditions was pointed out by Dean and Parduhn (this volume) for Cretaceous black shale interbedded with red and green claystone in the Angola Basin at DSDP Site 530. This 160 -m-thick interbedded sequence is Albian through Coniacian-Santonian in age and represents the upper part of mid-Cretaceous black-shale deposition in the Atlantic. The black-shale beds in this sequence have an average of 5.4 weight percent organic carbon, compared with less than $0.5 \%$ for red and green claystones in the sequence (Meyers, Brassell, and Huc, this volume). Geometric-mean concentrations of trace elements from each lithology show that concentrations of $\mathrm{As}, \mathrm{Cd}, \mathrm{Co}, \mathrm{Cr}, \mathrm{Cu}, \mathrm{Mo}, \mathrm{Ni}, \mathrm{Pb}, \mathrm{V}$, and $\mathrm{Zn}$ are all higher in black shales than in red and green claystones (Fig. 8). Concentrations of $\mathrm{Ba}$ and $\mathrm{Fe}$ are generally higher in red claystone than in green claystone and black shale. Concentrations of $\mathrm{Mn}$ are generally higher in green claystone than red claystone, and much lower in black shale. Dean and Gardner (1982) found the same general relationships in cycles of black shale and green and red claystone from DSDP Site 367 off northwest Africa; $\mathrm{Cr}, \mathrm{Mo}, \mathrm{Ni}, \mathrm{Zn}$, and $\mathrm{V}$ were enriched in black shale, whereas $\mathrm{Co}$ and $\mathrm{Cu}$ were of about equal concentrations in all lithologies (Fig. 9).

The maximum concentrations of elements in the Site 530 black shales, however, do not all occur at the same depth (Fig. 10). Concentrations of $\mathrm{Cd}, \mathrm{Zn}, \mathrm{V}, \mathrm{Cu}$, and Mo are highest in the part of the section where black shale beds are most abundant, which suggests that they have not migrated far from their organic-matter source. These elements also are among the ones most commonly reported to be enriched in black shales from other areas.

The pattern of trace-element mobility in the blackshale sequence at Site 530, illustrated in Figure 10, is in accordance with basic concepts concerning the control of redox reactions and solubility of various redox-sensitive elements in pore waters by a combination of organic complexing (e.g., Elderfield, 1981) and sulfide-carbonate equilibria (e.g., Berner, 1980; Suess, 1979). Iron and manganese are examples of redox-sensitive elements that behave differently in anoxic sediments, and this is reflected in the black-shale sequence at Site 530 . The enrichment pattern for the concentration of iron in blackshale beds is most similar to that of barium in that the

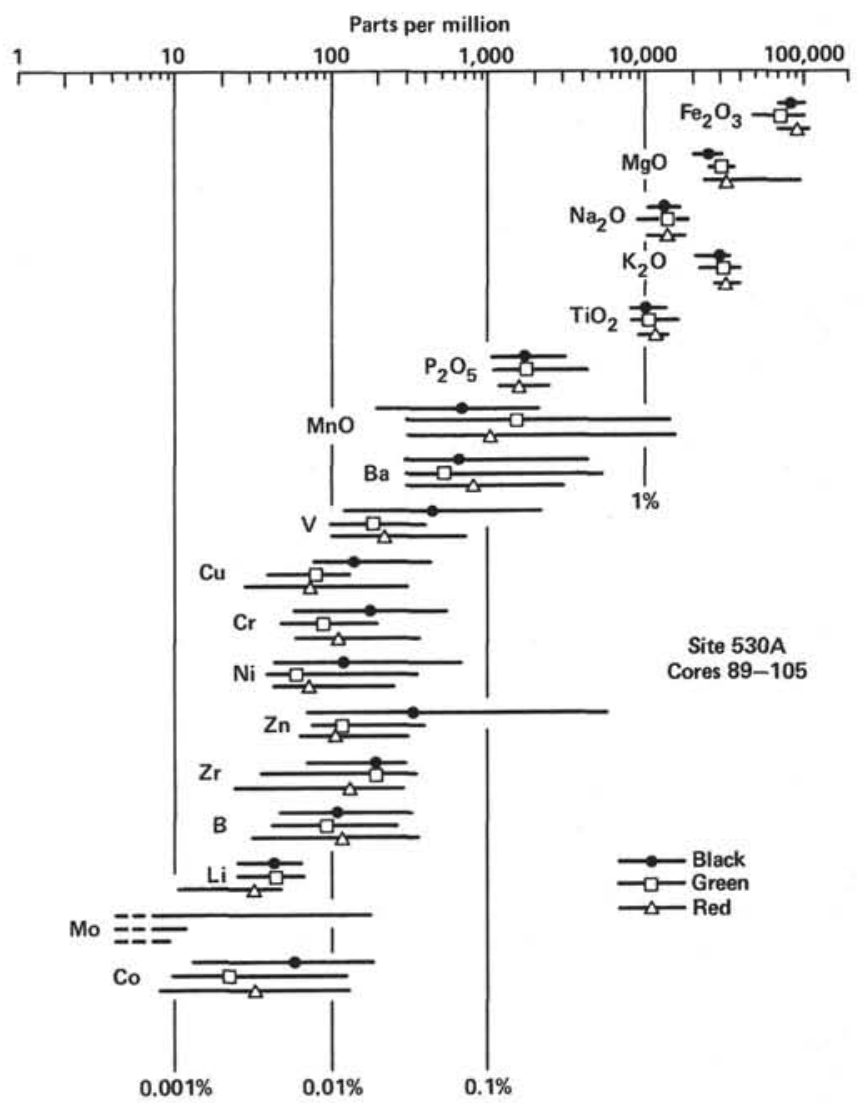

Figure 8. Observed range (length of bar) and geometric mean (symbol) of concentrations of major-element oxides and trace elements in samples of red and green claystone and black shale from DSDP Hole 530A, Cores 89-105.

concentrations are highest in the upper part of the blackshale-bearing section and lowest in the lower part of the section, the exact opposite of the enrichment pattern for manganese (Fig. 10). In addition, the concentration of iron is not significantly correlated with concentrations of any of the trace elements that are closely associated with the black shale beds. The concentration of iron is about the same in black shale and green claystone, and perhaps slightly enriched in red claystone (Fig. 8). Elderfield (1981) demonstrated that up to 80 percent of iron dissolved in pore waters of anoxic sediments is complexed by dissolved organic molecules; most of these organic complexes have large ionic radii and diffuse slowly in fine-grained sediment. The solubility of iron, therefore, initially is controlled by organic complexing, and iron resides near its initial site of reduction and solubilization eventually to be precipitated as iron sulfide or as iron oxyhydroxides in sediments where the Eh is sufficiently high. Dissolved iron may migrate as much as several centimeters to local sites of sulfide or oxyhydroxide precipitation, but probably not over distances of tens of meters. Manganese, to the contrary, is much more mobile than iron because it does not form many organic complexes (Elderfield, 1981) and does not precipitate as sulfide minerals. In fact, manganese may be solubilized and desolubilized several times as the low-Eh interface moves upward in the sediment column, where- 
A

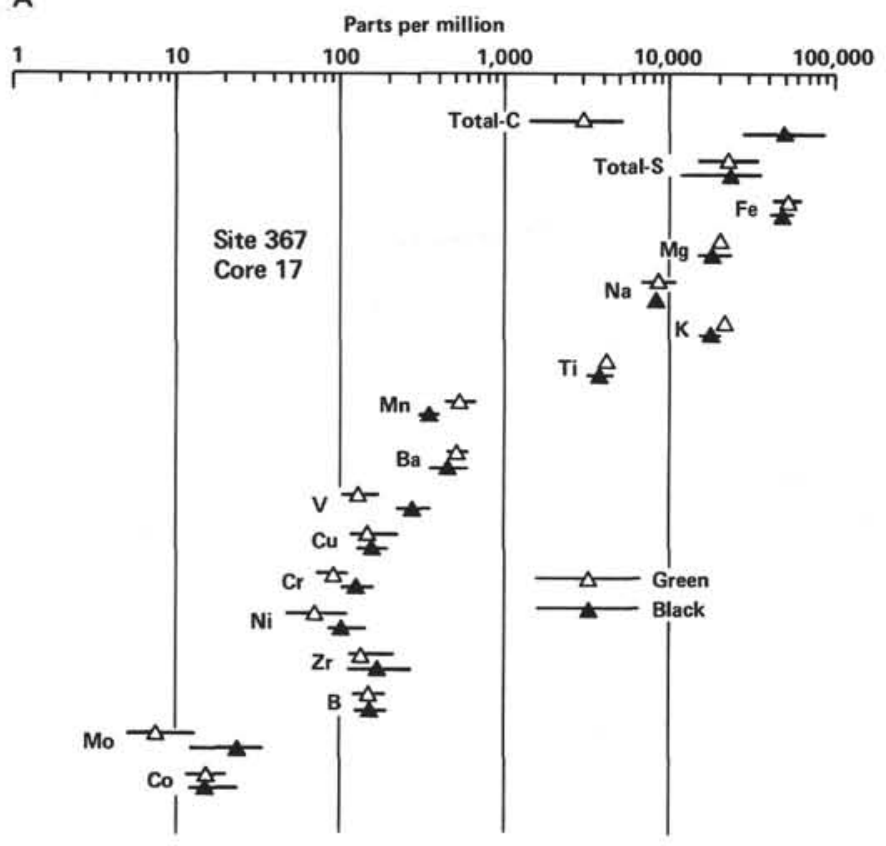

B

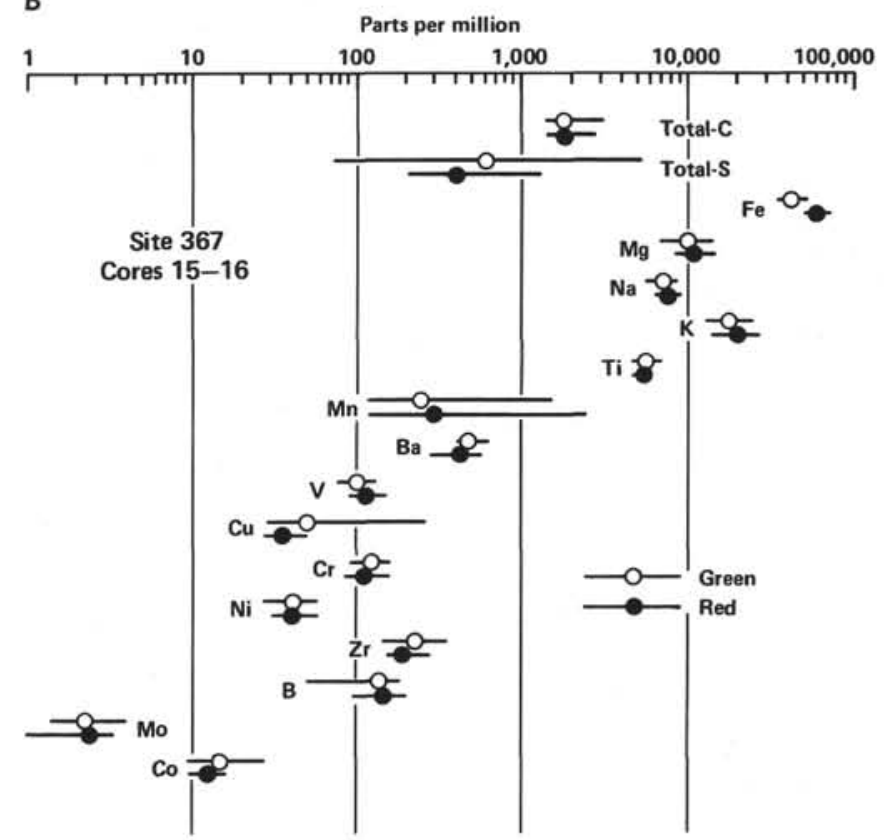

Figure 9. A. Observed range (length of bar) and geometric mean (symbol) of concentrations of major-element oxides and trace elements on a carbonate-free basis for samples of interbedded black shale and green claystone from DSDP Hole 367, Core 17. B. Observed range (length of bar) and geometric mean (symbol) of concentrations of major-element oxides and trace elements on a carbonate-free basis for samples of interbedded green and red claystone from DSDP Hole 367, Cores 15 and 16.

as iron may remain behind depending upon the extent of the reduction. Some anoxic sediments may be relatively enriched in manganese due to local precipitation of Mnrich carbonate phases (e.g., Suess, 1979 and Pederson and Price, 1982). That the high manganese concentrations in black-shale beds at Site 530 (Fig. 10) probably are associated with carbonates is indicated by a high positive correlation between concentrations of $\mathrm{Mn}$ and $\mathrm{Ca}(\mathrm{r}=0.85$; Table 3$)$. The carbonate content of the black shales is highest in the lower part of the section, which explains the higher concentration of manganese there. Any manganese that was not coprecipitated with carbonate quickly diffused out of the sediment.

Variation in concentrations of $\mathrm{Cd}, \mathrm{Cu}, \mathrm{Mo}, \mathrm{V}$, and $\mathrm{Zn}$ all are similar as evidenced by similar patterns of concentration versus depth (Fig. 10) and high correlation coefficients (Table 3). Concentrations of Mo, V, $\mathrm{Zn}$, and $\mathrm{Cu}$ in organic matter and (or) biogenic silica have been reported by many investigators (e.g., Volkov and Fomina, 1974; Presley et al., 1972; Leinen and Stakes, 1979), but once solubilized these elements can diffuse until they are scavenged by sulfides. Concentrations of these elements in Site 530 black shales are all positively correlated with the concentration of $\mathrm{P}_{2} \mathrm{O}_{5}$ (Table 3) and negatively correlated with $\mathrm{SiO}_{2}$, which suggests an organic association. There is no correlation between $\mathrm{SiO}_{2}$ and $\mathrm{Al}_{2} \mathrm{O}_{3}$ and the $\mathrm{Si}: \mathrm{Al}$ ratio is high (average of 4.8) for black, red, and green lithologies, which suggests that much of the $\mathrm{SiO}_{2}$ is biogenic, although no recognizable remains of siliceous organisms were observed (Site 530, summary chapter, this volume). This biogenic silica must be a dilutant rather than a source of trace metals, or else the biogenic silica and trace metals have become efficiently separated during diagenesis.

The distributions of concentrations of $\mathrm{Pb}$ and $\mathrm{Cr}$ with depth are very different from those of most other trace elements (Fig. 10). Concentrations of $\mathrm{Co}$ and $\mathrm{Ni}$ are highly correlated $(r=0.80$; Table 3$)$ and have maxima in certain black-shale beds (Fig. 10), but not in the same beds as most of the other trace elements. In the interbedded red claystones, concentrations of $\mathrm{Co}, \mathrm{Cr}, \mathrm{Cu}$, $\mathrm{Ni}, \mathrm{V}$, and $\mathrm{Zn}$ are all lower than in the black shales but are all highly correlated with each other $(r>0.90$ for all correlations) and are all highly correlated with the concentration of barium ( $r>0.8$ for all correlations).

Brumsack (1980) analyzed 38 samples of Cretaceous black shale from the Atlantic having more than 1\% organic carbon (average of $6.12 \%$; Table 2), and compared the values obtained from 11 samples of associated lithologies containing 0.5 to $1.0 \%$ organic carbon, and 38 samples of associated lithologies containing less than $0.5 \%$ organic carbon. His results showed enrichment of $\mathrm{Cu}, \mathrm{Cr}, \mathrm{Mo}, \mathrm{Ni}$, and $\mathrm{Zn}$ in organic-carbon-rich beds relative to associated organic-carbon-poor beds. Fe and Mn concentrations were highest in black and red beds but not in green beds. Tables 1 and 2 compare Brumsack's (1980) data with those from Site 530 (Dean and Parduhn, this volume). The mean values for samples from Site 530 given by Dean and Parduhn and plotted in Figure 8 are geometric means, which are more realistic measures of central tendency because trace-element concentrations usually have frequency distributions that more closely approximate log-normal than normal distributions. In Tables 1 and 2, however, the Site 530 data are expressed as arithmetic means for purposes of com- 

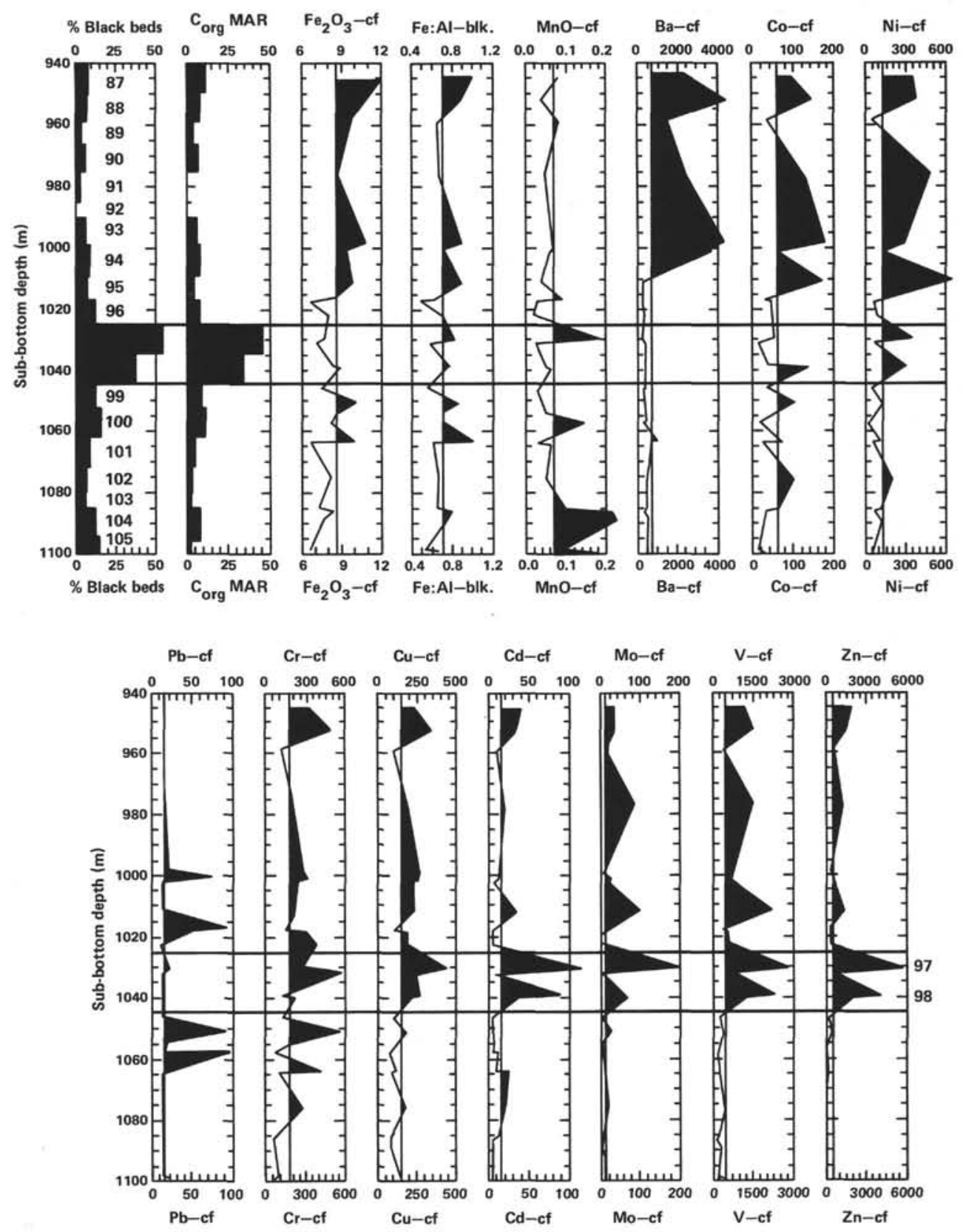

Figure 10. Plots of carbonate-free (cf) concentrations versus depth for $\mathrm{Fe}_{2} \mathrm{O}, \mathrm{MnO}, \mathrm{Ba}, \mathrm{Co}, \mathrm{Ni}, \mathrm{Pb}, \mathrm{Cr}$, $\mathrm{Cu}, \mathrm{Cd}, \mathrm{Mo}, \mathrm{V}$, and $\mathrm{Zn}$ in samples of black shale from DSDP Site 530, southern Angola Basin. Concentrations of $\mathrm{Fe}_{2} \mathrm{O}$ and $\mathrm{MnO}$ are in percent; all other concentrations are in parts per million. The Fe:Al ratio in black-shale samples, the percentage of black-shale beds in each 9.5 -m cored interval, and the mass accumulation rate (MAR; $\mathrm{g} / \mathrm{cm}^{2} / \mathrm{m}$.y.) of organic carbon for each $9.5-\mathrm{m}$ cored interval also are plotted. The vertical line through each concentration plot is at the geometric-mean concentration for that element or oxide. All values greater than the geometric mean are shaded. The numbers (87-105) within the plot for percentage of black-shale beds are the numbers of each core. The two horizontal lines drawn through all plots are drawn at the top of Core 97 and the bottom of Core 98 and mark the zone of maximum black-shale-bed concentration (Fig. 3).

parison. The average concentrations of $\mathrm{Cr}, \mathrm{Cu}, \mathrm{Ni}$, and $\mathrm{Pb}$ in both sets of black-shale samples are comparable, whereas Brumsack's (1980) average concentrations of Mo, V, and $\mathrm{Zn}$ are about twice those of the Site 530 black shales, and concentrations of $\mathrm{Ba}, \mathrm{Cd}$, and $\mathrm{Co}$ are higher in Site 530 black shales. Some of these differences may reflect analytical uncertainties, but it appears that, in general, Cretaceous black shales from the Atlantic are similarly enriched in trace elements.

In comparison to modern anoxic sediments from a variety of environments, the Site 530 black shales are at least as enriched or more enriched in $\mathrm{Ba}, \mathrm{Cd}, \mathrm{Co}$, $\mathrm{Cr}, \mathrm{Cu}, \mathrm{Ni}, \mathrm{Pb}, \mathrm{V}$, and $\mathrm{Zn}$ (on a carbonate-free basis; Table 1). Of the trace elements analyzed, only Mo is de- 
Table 3. Correlation coefficients among concentrations of selected trace elements and major-element oxides in 28 samples of black shale from DSDP Site 530 (computed from data of Dean and Parduhn, this volume).

\begin{tabular}{|c|c|c|c|c|c|c|c|c|c|c|c|c|c|c|c|c|}
\hline & $\mathrm{Al}_{2} \mathrm{O}_{3}$ & $\mathrm{Fe}_{2} \mathrm{O}_{3}$ & $\mathrm{MgO}$ & $\mathrm{CaO}$ & $\mathrm{K}_{2} \mathrm{O}$ & $\mathrm{P}_{2} \mathrm{O}_{5}$ & $\mathrm{MnO}$ & $\mathrm{Ba}$ & Co & $\mathrm{Cr}$ & $\mathrm{Cu}$ & Mo & $\mathrm{Ni}$ & $\mathrm{Pb}$ & v & $\mathrm{Zn}$ \\
\hline $\mathrm{SiO}_{2}$ & 0.01 & -0.49 & 0.64 & 0.20 & 0.15 & -0.63 & 0.18 & -0.07 & -0.56 & -0.35 & -0.86 & -0.75 & -0.82 & 0.18 & -0.87 & -0.75 \\
\hline $\mathrm{Al}_{2} \mathrm{O}_{3}$ & & 0.08 & 0.34 & -0.48 & 0.71 & -0.17 & -0.41 & 0.30 & 0.01 & 0.06 & -0.14 & -0.35 & -0.17 & 0.21 & -0.30 & -0.39 \\
\hline $\mathrm{Fe}_{2} \mathrm{O}_{3}$ & & & -0.43 & -0.26 & 0.20 & 0.10 & -0.18 & 0.22 & 0.66 & 0.36 & 0.31 & 0.06 & 0.51 & 0.04 & 0.22 & 0.11 \\
\hline $\mathrm{MgO}$ & & & & 0.20 & 0.35 & -0.38 & 0.20 & -0.25 & -0.45 & -0.33 & -0.57 & -0.56 & -0.68 & 0.24 & -0.68 & -0.59 \\
\hline $\mathrm{CaO}$ & & & & & -0.39 & 0.19 & 0.85 & -0.22 & -0.40 & -0.45 & -0.11 & 0.23 & -0.21 & 0.08 & -0.02 & 0.17 \\
\hline $\mathrm{K}_{2} \mathrm{O}$ & & & & & & -0.09 & -0.22 & 0.25 & 0.10 & 0.01 & -0.35 & -0.46 & -0.17 & 0.00 & -0.45 & -0.49 \\
\hline $\mathrm{P}_{2} \mathrm{O}_{5}$ & & & & & & & 0.18 & 0.05 & 0.23 & 0.20 & 0.55 & 0.66 & 0.55 & -0.18 & 0.61 & 0.47 \\
\hline $\mathrm{MnO}$ & & & & & & & & -0.19 & -0.37 & -0.56 & -0.21 & 0.16 & -0.20 & 0.03 & -0.08 & 0.11 \\
\hline $\mathrm{Ba}$ & & & & & & & & & 0.51 & 0.26 & 0.40 & -0.07 & 0.35 & -0.07 & 0.10 & 0.00 \\
\hline Co & & & & & & & & & & 0.38 & 0.49 & 0.31 & 0.80 & -0.11 & 0.46 & 0.18 \\
\hline $\mathrm{Cr}$ & & & & & & & & & & & 0.53 & 0.03 & 0.18 & 0.13 & 0.15 & 0.05 \\
\hline $\mathrm{Cu}$ & & & & & & & & & & & & 0.67 & 0.63 & -0.11 & 0.80 & 0.76 \\
\hline Mo & & & & & & & & & & & & & 0.66 & -0.10 & 0.87 & 0.85 \\
\hline $\mathrm{Ni}$ & & & & & & & & & & & & & & -0.23 & 0.82 & 0.55 \\
\hline $\mathrm{Pb}$ & & & & & & & & & & & & & & & -0.22 & 0.17 \\
\hline V & & & & & & & & & & & & & & & & 0.90 \\
\hline
\end{tabular}

pleted in the Site 530 black shales relative to modern anoxic sediments. In general, the trace element enrichments in Site 530 deep-water black shales, as well as most of those reported by Brumsack (1980) and Dean and Gardner (1982) are higher than those in sediments from modern anoxic environments from the Black Sea and Bunnefjord (Table 1). These two modern anoxic environments have anoxic water columns above the sediment rather than only anoxic sediment-interstitial waters. The ranges and mean concentrations of most trace elements in Site 530 black shales also are larger than those in very organic-carbon-rich green muds deposited within an intense oxygen-minimum zone in Walvis Bay, Southwest Africa (Table 2).

Enrichments of $\mathrm{Cd}, \mathrm{Mo}, \mathrm{Ni}, \mathrm{Co}$, and $\mathrm{Zn}$ can be related to enhanced supply and preservation of organic matter (e.g., Bruland et al., 1980), with subsequent liberation during decomposition of the organic matter and scavenging by sulfides during early diagenesis in anoxic sediment. The high concentrations of $\mathrm{Zn}$ and $\mathrm{Co}$ also may have been supplied directly to the sediment as metal sulfide particles produced in an anoxic, sulfide-rich water column as in the modern anoxic Black Sea (e.g., Spencer et al., 1972; Brewer and Spencer, 1974), but there is other evidence to suggest that the black shales at Site 530, and probably in much of the Cretaceous Atlantic Ocean, were not deposited under an entirely anoxic water column.

A possible example of trace-element enrichment by pore waters in oxidized sediment overlying reduced sediment was recovered at DSDP Site 105 in the North American Basin of the western North Atlantic Ocean. Here, the middle Cretaceous black shale unit is overlain by Upper Cretaceous-lower Tertiary red and green clays (Lancelot et al., 1972). Jansa et al. (1979) interpreted the oxidized clays as having been deposited in an oxygenated, pelagic deep-sea environment similar to the environment presently accumulating pelagic clays in the central North Pacific. This unit was recovered at eight other sites in the North American Basin (Jansa et al., 1979), but at Site 105 the multicolored clays are enriched in heavy metals, especially $\mathrm{Mn}, \mathrm{Zn}, \mathrm{Cu}, \mathrm{Pb}, \mathrm{Cr}, \mathrm{Ni}$, and
V; this led Lancelot et al. (1972) to suggest that the clays were enriched in metals by hydrothermal volcanic exhalations and in this regard were analogous to metal-enriched sediments associated with Red Sea brine deposits, or metal-enriched basal sediments overlying basement along the East Pacific Rise.

Arthur (1979b) proposed that the metals in the oxidized clays at Site 105 were not derived from volcanic exhalations but from chemically reduced metallic ions in the anoxic pore waters of the underlying black shales. The reduced ions in pore waters diffused upward and were oxidized in the slowly accumulating Upper Cretaceous clays. The equivalent clays at DSDP Site 367 in the Cape Verde Basin in the eastern North Atlantic, however, are not enriched in any metals, nor are there any significant differences in metal concentrations between interbedded red and green clays (Dean and Gardner, 1982).

The relative mobility of trace elements in anoxic pore waters is of interest because we would like to understand the patterns of trace-element enrichment in black shales and to use them as indicators of depositional environment and paleocean chemistry. The fact that some elements may migrate over fairly large distances (tens of meters or more) in anoxic pore waters may invalidate bulk analyses of black-shale beds if only a few selected beds are analyzed. For example, if we had only analyzed black-shale beds at the bottom of the section at Site 530 (below 1050 m, Fig. 10), we would not have found the most significant trace-element enrichments. It is also important to examine the compositions of interbedded lithologies because of trace-element migration. Relative concentrations (parts per million) of trace elements also may be misleading because of dilution effects in highsedimentation-rate sequences. For example, a comparison of trace-element concentrations between black shales and average red clay (Table 1) suggests that average pelagic red clay is as enriched in $\mathrm{Co}, \mathrm{Cu}, \mathrm{Ni}, \mathrm{Pb}$, and $\mathrm{Zn}$ as many black shales. However, the accumulation rates of these trace elements probably are higher in most black shales because the average rates of bulksediment accumulation are higher. 
Table 4. Mass accumulation rates of selected components in red, green, and black lithologies, Site 530.

\begin{tabular}{|c|c|c|c|c|c|c|c|c|c|c|c|c|c|c|}
\hline Core & $\begin{array}{l}\text { Depth } \\
\text { (m) }\end{array}$ & $\begin{array}{l}\text { Recovery } \\
(\mathrm{cm})\end{array}$ & $\begin{array}{c}\text { Black } \\
\text { beds } \\
(\%)\end{array}$ & $\begin{array}{l}\text { Red } \\
\text { beds } \\
(\%)\end{array}$ & $\begin{array}{l}\text { Green } \\
\text { beds } \\
(\%)\end{array}$ & $\begin{array}{l}\text { Peeriod } \\
\left(10^{3} \text { yr. }\right)^{\mathrm{a}}\end{array}$ & $\begin{array}{c}\mathrm{Zn}^{\mathrm{b}} \text { in } \\
\text { black beds } \\
(\%)\end{array}$ & $\begin{array}{c}\mathrm{Cr}^{\mathrm{b}} \text { in } \\
\text { black beds } \\
(\%)\end{array}$ & $\begin{array}{c}\mathrm{Ni}^{\mathrm{b}} \text { in } \\
\text { black beds } \\
(\%)\end{array}$ & $\begin{array}{c}\mathrm{Zn}^{\mathrm{b}} \text { in } \\
\text { red beds } \\
(\%)\end{array}$ & $\begin{array}{c}\mathrm{Cr}^{\mathrm{b}} \text { in } \\
\text { red beds } \\
(\%)\end{array}$ & $\begin{array}{l}\mathrm{Ni}^{\mathrm{b}} \text { in } \\
\text { red beds } \\
(\%)\end{array}$ & $\begin{array}{c}\mathrm{Zn}^{\mathrm{b}} \text { in } \\
\text { green beds } \\
(\%)\end{array}$ & $\begin{array}{l}\mathrm{Cr}^{\mathrm{b}} \text { in } \\
\text { green beds } \\
(\%)\end{array}$ \\
\hline 87 & $940-949$ & 703 & 8 & 72 & 20 & 40 & 0.180 & 0.029 & 0.036 & 0.010 & 0.011 & 0.004 & 0.008 & 0.015 \\
\hline 88 & $949-958$ & 448 & 6 & 74 & 20 & 61 & 0.140 & 0.045 & 0.039 & 0.007 & 0.011 & 0.004 & 0.013 & 0.019 \\
\hline 89 & $958-967$ & 922 & 3 & 87 & 10 & 70 & - & - & - & 0.025 & 0.025 & 0.015 & - & - \\
\hline 90 & $967-976$ & 446 & 5 & 85 & 10 & 61 & 0.110 & 0.018 & 0.049 & - & - & - & 0.013 & 0.015 \\
\hline 91 & $976-985$ & 574 & 0 & 95 & 5 & 393 & 0.0 & 0.0 & - & 0.011 & 0.010 & 0.006 & 0.015 & 0.015 \\
\hline 92 & $985-990$ & 0 & 0 & 0 & 0 & 0 & 0.0 & 0.0 & 0.0 & 0.0 & 0.0 & 0.0 & 0.0 & 0.0 \\
\hline 93 & $990-999$ & 918 & 4 & 90 & 6 & 52 & 0.014 & 0.025 & 0.030 & - & - & - & - & - \\
\hline 94 & $999-1,008$ & 273 & 6 & 79 & 15 & 37 & 0.042 & 0.025 & 0.015 & 0.007 & 0.008 & 0.006 & 0.016 & 0.012 \\
\hline 95 & $1,008-1,017$ & 656 & 5 & 80 & 15 & 61 & 0.009 & 0.092 & 0.065 & 0.009 & 0.009 & 0.007 & 0.031 & 0.012 \\
\hline 96 & $1,017-1,026$ & 795 & 9 & 45 & 46 & 46 & 0.023 & 0.033 & 0.008 & - & - & - & 0.014 & 0.008 \\
\hline 97 & $1,026-1,035$ & 607 & 52 & 0 & 48 & 22 & 0.275 & 0.040 & 0.006 & - & - & - & 0.013 & 0.010 \\
\hline 98 & $1,035-1,044$ & 501 & 36 & 0 & 64 & 10 & 0.300 & 0.016 & 0.030 & - & - & - & 0.024 & 0.007 \\
\hline 99 & $1,044-1,053$ & 735 & 9 & 20 & 71 & 33 & 0.019 & 0.034 & 0.009 & - & - & - & 0.007 & 0.007 \\
\hline 100 & $1,053-1,062$ & 672 & 12 & 25 & 66 & 39 & 0.012 & 0.020 & 0.010 & - & - & - & 0.010 & 0.008 \\
\hline 101 & $1,062-1,071$ & 995 & 5 & 35 & 60 & 129 & 0.013 & 0.042 & 0.012 & 0.009 & 0.009 & 0.009 & - & - \\
\hline 102 & $1,071-1,080$ & 800 & 3 & 70 & 25 & 222 & 0.013 & 0.027 & 0.020 & 0.006 & 0.006 & 0.004 & 0.010 & 0.010 \\
\hline 103 & $1,080-1,085$ & 600 & 2 & 60 & 37 & 222 & 0.014 & 0.008 & 0.011 & - & - & - & 0.010 & 0.006 \\
\hline 104 & $1,085-1,094$ & 790 & 8 & 0 & 94 & 219 & 0.012 & 0.010 & 0.010 & - & - & - & 0.010 & 0.009 \\
\hline 105 & $1,094-1,103$ & 800 & 10 & 20 & 72 & 55 & 0.014 & 0.010 & 0.005 & 0.009 & 0.006 & 0.008 & 0.008 & 0.008 \\
\hline
\end{tabular}

a Based on average accumulation rates of $14.6 \mathrm{~m} / \mathrm{m} . \mathrm{y}$. for Cores $87-94$ and $9 \mathrm{~m} / \mathrm{m} . \mathrm{y}$, for Cores $95-105$.

b Data of Dean and Parduhn (this volume). Dash indicates no analyses for that core.

c MAR for bulk sediment = [(accumulation rate) $100(1-$ porosity $/ 100)$ grain density] (Thiede and Rea, 1981), where accumulation rate $=14.6 \mathrm{~m} / \mathrm{m} . \mathrm{y}$. for Cores $87-94$ and $9.0 \mathrm{~m} / \mathrm{m} . \mathrm{y}$. for Cores $95-105$; porosity $=33 \%$ for all cores, and grain density is assumed to be $2.7 \mathrm{~g} / \mathrm{cm}^{3}$.

$\mathrm{d}_{\text {MAR for }} \mathrm{C}_{\text {org }}=$ (MAR of black beds) $(5.4 / 100)$, where 5.4 is the grand average concentration of organic carbon in black-shale samples analyzed by Meyers, Brassell, and Huc (this volume)

e MAR for trace elements $=$ (MAR of each colored bed) ( $\%$ of trace element in each colored bed $/ 100)$.

For each 9.5-m cored interval in the black-shale-bearing sequence at Site 530 , we calculated mass accumulation rates (MAR; $\mathrm{g} / \mathrm{cm}^{2} / \mathrm{m}$.y.) for bulk sediment, for each different-colored lithology, for organic carbon, for three trace-elements $(\mathrm{Zn}, \mathrm{Cr}$, and $\mathrm{Ni})$ in each differentcolored lithology, and for the sum of each of the three trace elements (Table 4). An average black shale was assumed to have a concentration of organic carbon of $5.4 \%$, which is the average of analyses reported by Meyers, Brassell, and Huc (this volume). The MARs were calculated (Table 4) using (1) estimates of the percentages of black, red, and green beds in the recovered part of each 9.5-m cored interval, (2) biostratigraphically determined accumulation rates and porosity (Site 530 summary, this volume), and (3) an average grain density of $2.7 \mathrm{~g} / \mathrm{cm}^{3}$. The MAR for organic carbon varies from 0 to $46 \mathrm{~g} / \mathrm{cm}^{2} / \mathrm{m}$.y. As expected, maximum values for organic-carbon and trace-element MARs occur in Cores 97 and 98 where black-shale beds are far more abundant than in any other part of the section (Fig. 10). Maximum MARs for $\mathrm{Zn}, \mathrm{Cr}$, and $\mathrm{Ni}$ in black-shale beds are $2.38,0.35$, and $0.18 \mathrm{~g} / \mathrm{cm}^{2} / \mathrm{m} . \mathrm{y}$., respectively, in Cores 97 and 98. MARs for these elements are all about 0.01 to $0.02 \mathrm{~g} / \mathrm{cm}^{2} / \mathrm{m}$.y. in the lower part of the blackshale-bearing sequence, and 0.01 to $0.4 \mathrm{~g} / \mathrm{cm}^{2} / \mathrm{m}$.y. in the upper part of the sequence (Table 4). The changes in $\mathrm{Zn}$ MAR are the most extreme. Maximum values of total MARs for $\mathrm{Zn}, \mathrm{Cr}$, and $\mathrm{Ni}$ are $2.48,0.66$, and $0.42 \mathrm{~g} / \mathrm{cm}^{2} /$ m.y., respectively, and only the maximum for $\mathrm{Zn}$ occurs in the zone of maximum black-shale concentration in Cores 97 and 98. Total MARs for all three elements are uniformly low in the lower part of the black-shale-bearing section, and relatively high in the upper part of the section (Cores 87 to 96). For comparison, Leinen and Stakes (1979) calculated average MARs of $\mathrm{Zn}$ and Ni of $0.17 \mathrm{~g} / \mathrm{cm}^{2} / \mathrm{m}$.y. and $0.08 \mathrm{~g} / \mathrm{cm}^{2} / \mathrm{m}$.y. respectively for sediment on the crest of the East Pacific Rise, and 0.06 $\mathrm{g} / \mathrm{cm}^{2} / \mathrm{m}$.y. and $0.03 \mathrm{~g} / \mathrm{cm}^{2} / \mathrm{m}$.y. respectively, for pelagic sediment in the eastern equatorial Pacific Ocean. The average MARs from Leinen and Stakes (1979) are somewhat higher than the average MARs of Site 530 black shales, but lower than total MARs in all cores except those in the lower part of the section. As we expected, the percentages of total MAR for each element that are contributed by black shale are highest in Cores 97 and 98 , but black shales also contribute significant proportions of the total MARs for $\mathrm{Zn}$ and $\mathrm{Ni}$ in Cores above 96 (as much as $63 \%$ of the Zn MAR in Core 87), although black-shale beds comprise less than $8 \%$ of this part of the section (Fig. 3).

Site 530 probably is an example of the lower limit of trace-element accumulation in Cretaceous black shales. The organic-carbon accumulation rates are low (maximum of $46 \mathrm{~g} / \mathrm{cm}^{2} / \mathrm{m}$.y.) compared with other Atlantic Cretaceous black-shale sequences. For example, Arthur and Natland (1979) calculated that organic carbon in the Aptian-lower Albian black-shale sequence at Site 361 in the Cape Basin accumulated at an average rate of $258 \mathrm{~g}$ / $\mathrm{cm}^{2} / \mathrm{m}$.y., and organic carbon in lower to middle Albian black, dolomitic sapropels, and marly limestones accumulated at rates of about $500 \mathrm{~g} / \mathrm{cm}^{2} / \mathrm{m}$.y. We calculated that organic carbon in Albian-Turonian black shales at Site 367 in the southeastern North Atlantic off northwest Africa accumulated at rates of about $460 \mathrm{~g} /$ $\mathrm{cm}^{2} / \mathrm{m}$.y. using measured organic-carbon, porosity, and sedimentation-rate data of Lancelot, Seibold, et al., 1978. For the Site 367, we calculated $\mathrm{Zn}$ and Ni MARs of 90 and $50 \mathrm{~g} / \mathrm{cm}^{2} / \mathrm{m}$.y. respectively, using average concentrations of 330 and $180 \mathrm{ppm}$ respectively (data of Lange et al., 1978). These values clearly are at least two orders of magnitude higher than those in pelagic clays studied by Leinen and Stakes (1979). The trace-element 
Table 4. (Continued.)

\begin{tabular}{|c|c|c|c|c|c|c|c|c|c|c|}
\hline $\begin{array}{c}\mathrm{Ni}^{\mathrm{b}} \text { in } \\
\text { green beds } \\
(\%)\end{array}$ & $\begin{array}{c}\text { MAR } \\
\text { Bulk sed. } \\
\left(\mathrm{g} / \mathrm{cm}^{2} / \mathrm{m} . \mathrm{y} .\right)\end{array}$ & $\begin{array}{c}\text { MAR } \\
\text { Black beds } \\
\left(\mathrm{g} / \mathrm{cm}^{2} / \mathrm{m} . \mathrm{y} .\right)\end{array}$ & $\begin{array}{c}\text { MAR } \\
\text { Red beds } \\
\left(\mathrm{g} / \mathrm{cm}^{2} / \mathrm{m} . \mathrm{y} .\right)\end{array}$ & $\begin{array}{c}\text { MAR } \\
\text { Green beds } \\
\left(\mathrm{g} / \mathrm{cm}^{2} / \mathrm{m} . \mathrm{y} .\right)\end{array}$ & $\begin{array}{c}\text { MAR } \\
\operatorname{Corg}_{2} \\
\left(\mathrm{~g} / \mathrm{cm}^{2} / \mathrm{m} . y .\right)\end{array}$ & $\begin{array}{c}\text { MAR-Zn } \\
\text { in black } \\
\left(\mathrm{g} / \mathrm{cm}^{2} / \mathrm{m} . y .\right)\end{array}$ & $\begin{array}{c}\text { MAR-Cr } \\
\text { in black } \\
\left(\mathrm{g} / \mathrm{cm}^{2} / \mathrm{m} . \mathrm{y} .\right)\end{array}$ & $\begin{array}{c}\text { MAR-Ni } \\
\text { in black } \mathrm{b}^{\mathrm{e}} \\
\left(\mathrm{g} / \mathrm{cm}^{2} / \mathrm{m} . \mathrm{y} .\right)\end{array}$ & $\begin{array}{c}\text { MAR-Zn } \\
\text { in red } \\
\left(\mathrm{g} / \mathrm{cm}^{2} / \mathrm{m} . \mathrm{y} .\right)\end{array}$ & $\begin{array}{c}\text { MAR-Cr } \\
\text { in red } \mathrm{ed}^{\mathrm{e}} \\
\left(\mathrm{g} / \mathrm{cm}^{2} / \mathrm{m} . \mathrm{y} .\right)\end{array}$ \\
\hline 0.010 & 2,641 & 211 & 1,901 & 528 & 11 & 0.400 & 0.060 & 0.080 & 0.19 & 0.19 \\
\hline 0.005 & 2,641 & 158 & 1,954 & 528 & 8 & 0.220 & 0.070 & 0.060 & 0.14 & 0.21 \\
\hline- & 2,641 & 79 & 2,298 & 264 & 4 & 0.200 & 0.050 & 0.060 & 0.57 & 0.57 \\
\hline 0.008 & 2,641 & 132 & 2,245 & 264 & 7 & 0.140 & 0.020 & 0.060 & 0.25 & 0.22 \\
\hline 0.034 & 2,641 & 0 & 2,509 & 132 & 0 & 0.0 & 0.0 & 0.0 & 0.28 & 0.23 \\
\hline 0.0 & 0 & 0 & 0 & 0 & 0 & 0.0 & 0.0 & 0.0 & 0.0 & 0.0 \\
\hline - & 2,641 & 106 & 2,377 & 158 & 6 & 0.010 & 0.030 & 0.030 & 0.17 & 0.19 \\
\hline 0.007 & 2,641 & 158 & 2,086 & 396 & 8 & 0.070 & 0.040 & 0.020 & 0.15 & 0.17 \\
\hline 0.005 & 1,664 & 83 & 1,331 & 250 & 4 & 0.010 & 0.080 & 0.050 & 0.12 & 0.12 \\
\hline 0.006 & 1,664 & 150 & 749 & 765 & 8 & 0.030 & 0.050 & 0.010 & 0.07 & 0.07 \\
\hline 0.005 & 1,664 & 865 & 0 & 799 & 46 & 2.380 & 0.350 & 0.050 & 0.0 & 0.0 \\
\hline 0.006 & 1,664 & 599 & 0 & 1,065 & 32 & 1.800 & 0.100 & 0.180 & 0.0 & 0.0 \\
\hline 0.006 & 1,664 & 150 & 333 & 1,181 & 8 & 2.020 & 0.050 & 0.010 & 0.03 & 0.03 \\
\hline 0.006 & 1,664 & 200 & 832 & 1,098 & 11 & 0.020 & 0.040 & 0.020 & 0.07 & 0.07 \\
\hline- & 1,664 & 83 & 582 & 998 & 4 & 0.010 & 0.030 & 0.010 & 0.05 & 0.05 \\
\hline 0.005 & 1,664 & 50 & 1,165 & 832 & 3 & 0.010 & 0.010 & 0.010 & 0.07 & 0.07 \\
\hline 0.005 & 1,664 & 33 & 998 & 616 & 2 & 0.005 & 0.003 & 0.004 & 0.07 & 0.06 \\
\hline 0.008 & 1,664 & 133 & - & 1,564 & 7 & 0.020 & 0.010 & 0.015 & 0.0 & 0.0 \\
\hline 0.005 & 1,664 & 17 & 333 & 1,198 & 1 & 0.002 & 0.002 & 0.001 & 0.03 & 0.02 \\
\hline
\end{tabular}

MAR values for Site 367 also are much higher than those estimated for modern anoxic deep-basin sediments from the Black Sea (Table 5), although the MARs for organic carbon are about the same as those for Site 367.

Cretaceous black shales obviously were an important sink for trace metals in the Cretaceous Atlantic Ocean. We think that the above concepts and observations deserve further research, and may ultimately explain much of the variability in metal enrichment in black shales in general. Studies of major and trace-element geochemistry of black-shale sequences, in conjunction with studies of sulfur, organic carbon, and changes in sedimentation rate, also are needed.

\section{MODELS OF DEPOSITION}

\section{Bottom-Water Oxygenation}

Interbedding of sediments alternately rich and poor in organic matter can be the result of either fluctuating preservation of organic matter or fluctuating rate of supply of organic matter. Differential preservation can result if bottom waters at the site of accumulation are alternately oxic and anoxic (or near-anoxic). Therefore, alternating periods of oxygen-deficient and relatively well-oxygenated bottom waters may be required if the site of accumulation is on a basin floor. Cyclic variation in amount of organic matter deposited at a continental margin site can be explained by cyclic fluctuations in the thickness and intensity of a midwater oxygen-minimum layer. Both depositional models (basin deoxygenation and expansion and intensification of an oxygen-minimum layer) have been proposed to explain the accumulation of organic carbon-rich strata (e.g., Schlanger and Jenkyns, 1976; Ryan and Cita, 1977; Fischer and Arthur, 1977; Thiede and van Andel, 1977; Arthur and Schlanger, 1979). Both models require very low to zero concentrations of dissolved oxygen in part of the water column as a result of reduced advection of oxygenated water and (or) increased supply of organic matter, and both models imply that reducing conditions in the sediments (and therefore the increased degree of preservation of organic matter) are the result of anoxic or nearanoxic conditions in the overlying waters.

Black, laminated, $\mathrm{C}_{\text {org }}$-rich Cretaceous strata are so widespread in the Atlantic that a closed-basin model has been proposed as the most likely analog for the Early to middle Cretaceous South and North Atlantic basins. The implication is that there was a stable salinity stratification, either because of lower-salinity surface water overlying bottom water of more-normal salinity as in the modern Black Sea, or because of normal-salinity surface water overlying more-saline bottom water, which led to increased residence time of deep-water masses and gradual oxygen depletion with or without increased surface productivity. A higher-salinity bottom-water mass would have a lower oxygen solubility which, together with an increased residence time, would result in greater oxygen depletion. The salinity-stratification model is made even more plausible by the fact that isolated Atlantic basins were accumulating great thicknesses of evaporites in the Late Jurassic and again in the Aptian, and therefore probably were more saline as well as more stagnant in the Early Cretaceous. In contrast, Brass et al. (1982) suggested that sinking of warm, saline bottom water produced over warm, arid, extensive shelf areas could generate bottom-water turnover rates as high as those of modern thermohaline deep circulation. Model studies by Southam et al. (1982) suggest that it would be difficult to create a totally anoxic water column in the open ocean because of the delicate balance between oxygen demand and supply to deeper waters, and nutrient upwelling to support surface productivity. However, the Black Sea sediment record is proof that rapid variations in oxygenation and anoxia can occur in large, isolated basins (Deuser, 1974; Degens and Stoffers, 1976).

\section{Supply of Organic Carbon to Sediments}

We find it difficult, however, to explain all of the interbedding of more reduced and less-reduced strata by fluctuating deoxygenation of bottom waters particularly 
Table 4. (Continued.)

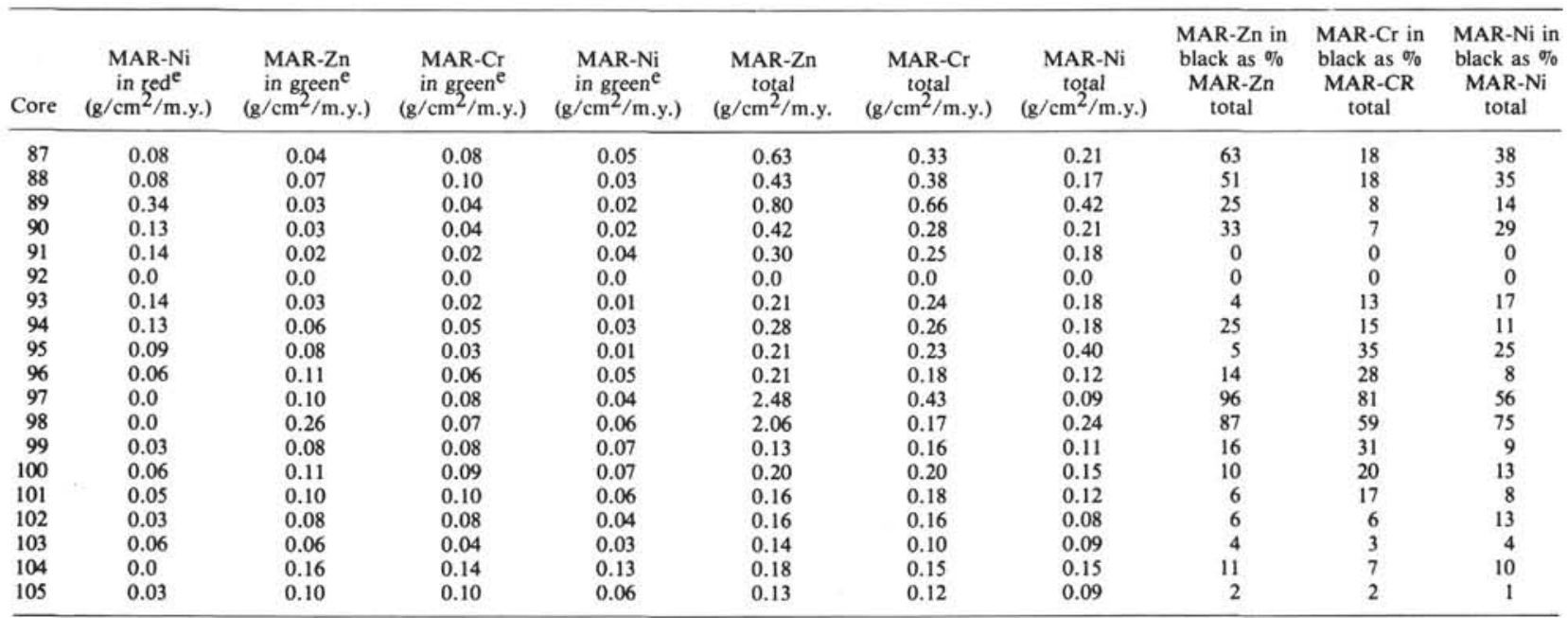

Table 5. Organic carbon, phosphorus, and trace-element concentrations and accumulation rates in modern sediments from the Black Sea.

\begin{tabular}{lcccccc}
\hline & \multicolumn{2}{c}{ Core no. $1432^{\mathrm{a}}$} & & \multicolumn{2}{c}{ Core no. $1462^{\mathrm{b}}$} \\
\cline { 2 - 3 } \cline { 5 - 6 } \cline { 5 - 6 } $\begin{array}{c}\text { Concentration } \\
(\text { wt. \%) }\end{array}$ & $\begin{array}{c}\text { Accumulation } \\
\text { rate } \\
\left(\mathrm{g} / \mathrm{cm}^{2} / \mathrm{m} . y .\right)\end{array}$ & $\begin{array}{c}\text { Concentration } \\
(\text { wt. \%) }\end{array}$ & $\begin{array}{c}\text { Accumulation } \\
\text { rate } \\
\left(\mathrm{g} / \mathrm{cm}^{2} / \mathrm{m} . \mathrm{y} .\right)\end{array}$ \\
\hline $\mathrm{C}_{\text {org }}$ & 2.08 & 178 & & 3.58 & 525 \\
$\mathrm{P}$ & 0.10 & 8.47 & & 0.17 & 24.9 \\
$\mathrm{Zn}$ & $91 \times 10^{-6}$ & 0.77 & & $67 \times 10^{-6}$ & 0.98 \\
$\mathrm{Ni}$ & $149 \times 10^{-6}$ & 1.26 & & $67 \times 10^{-6}$ & 0.98 \\
$\mathrm{Cu}$ & $56 \times 10^{-6}$ & 0.47 & & $37 \times 10^{-6}$ & 0.54 \\
$\mathrm{Cr}$ & $167 \times 10^{-6}$ & 1.41 & & $52 \times 10^{-6}$ & 0.54 \\
\hline
\end{tabular}

Note: Data of Hirst (1974); chronology from Ross and Degens (1974); bulksediment accumulation rates were computed using a dry-bulk density of $1.1 \mathrm{~g} / \mathrm{cm}^{3}$ (Keller, 1974).

a Depth, $2248 \mathrm{~m}$; average bulk-sediment accumulation rate, $8470 \mathrm{~g} / \mathrm{cm}^{2}$ /

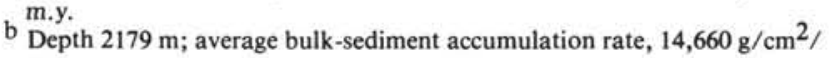
m.y.

in deep-basin settings. Most of the Jurassic and Cretaceous strata in the Atlantic contain abundant evidence that they were deposited in well-oxygenated bottom-water environments with at least some benthic infauna; only the interbedded dark-colored, organic carbon-rich lithologies suggest anaerobic depositional conditions because they commonly are laminated and apparently unbioturbated. Ekdale (1980) has shown that trace-fossil diversity varies within Cretaceous deep-water redox cycles, decreasing in organic-carbon-rich beds. Chondrites, a shallow-burrowing, branching ichnofossil type, is typically the last trace fossil found at the transition between a green or red and a black bed, and the first to colonize the bottom following the deposition of laminated black-clay layers. Our data from Site 530 confirm Ekdale's observations (Stow and Dean, this volume). This suggests that at least some of the redox cycles may be the result of a change in bottom-water oxygen concentration at or above the sediment/water interface. Interbedding of oxic-anoxic strata in the North Atlantic began in the Jurassic and continued at least into the
Eocene. However, only the Lower to middle Cretaceous and Eocene strata contain more than $1 \%$ organic carbon. It is not difficult to visualize abrupt changes in bottom-water circulation in a restricted basin such as the Early Cretaceous Atlantic Ocean, but it is difficult to imagine total stagnation of the Atlantic during the Late Cretaceous and Tertiary.

We therefore suggest that a third depositional model is necessary to explain some examples of interbedded more-reduced and less-reduced strata. This model involves varying diagenetic redox conditions in the sediments that are caused by varying oxygen demand within the sediments, largely in response to varying rates of accumulations of marine and (or) terrestrial organic detritus. Figure 11 summarizes our concept of how variations in rate of supply of organic matter may result in cyclic interbeds. This model does not necessitate major changes in bottom-water oxygen content, only that the supply of organic matter increases, either by periodic increases in surface productivity or by periodic redeposition of organic matter in the deep basin from sites on the outer shelf or slope where more organic matter is preserved in sediments, for example, under an oxygenminimum zone. Similar environmental interpretations of cyclic facies of the Liassic of Yorkshire, England, were made by Morris (1979) and Demaison and Moore (1980).

In the environment illustrated in Figure $11 \mathrm{~A}$, the rate of supply of organic detritus is low, the bottom waters are more or less well oxygenated, and the zero-oxygen isopleth is at some distance below the sediment-water interface, and red clay accumulates. Iron would be present mainly as ferric oxides and hydroxides and sulfur would be present mainly as $\mathrm{SO}_{4}^{2-}$. In the environment illustrated in Figure 11B, the rate of supply of organic detritus is higher (indicated diagrammatically by more black arrows); the bottom waters are still more or less well oxygenated but increased oxygen demand in the sediments, mainly from the increased decomposition of the organic matter, has resulted in a zero-oxygen isopleth at or near the sediment-water interface, and in the 


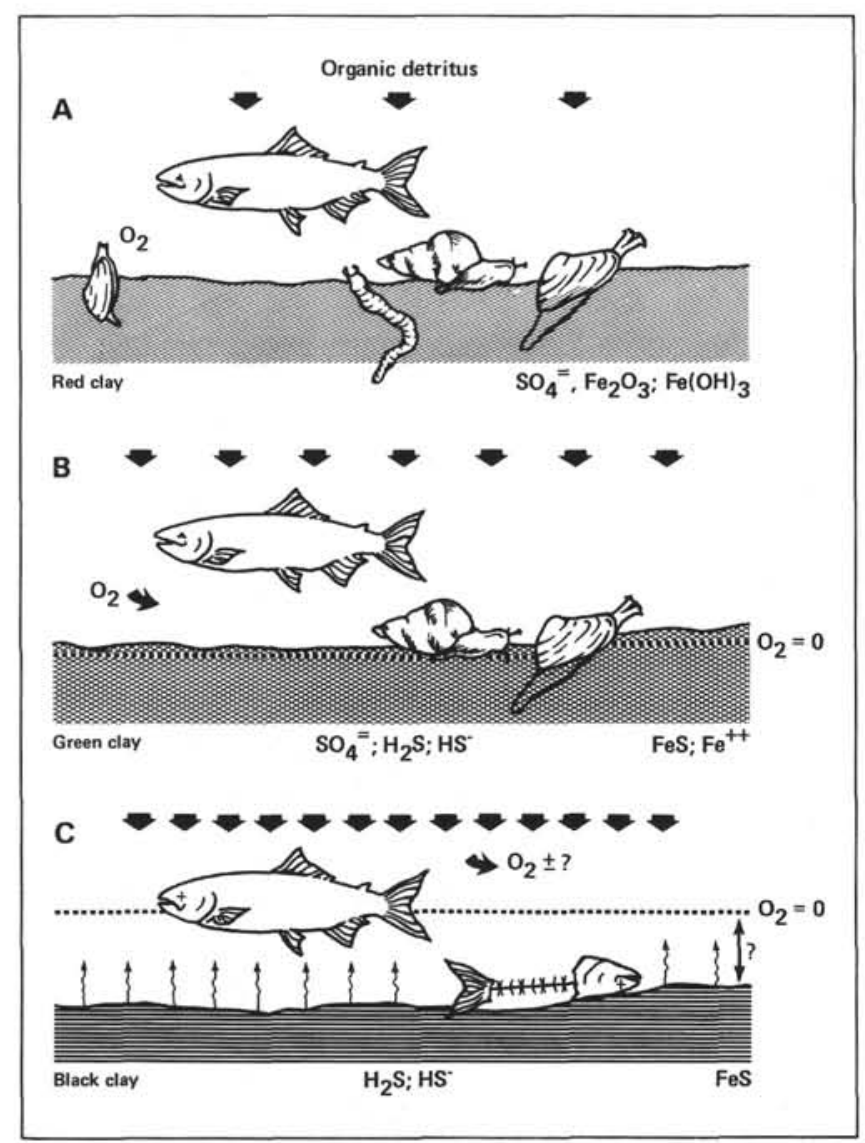

Figure 11. Variations in rate of organic decomposition and position of the boundary between oxidizing and reducing conditions $\left(\mathrm{O}_{2}=0\right.$ isopleth) with variations in rate of supply of organic detritus to deep-sea sediment. A. A low rate of supply of organic detritus resulting in red sediment. B. A moderate rate of supply of organic detritus resulting in green sediment. C. A rapid rate of supply of organic detritus resulting in black sediment. See text for discussion.

accumulation of green, reduced sediments. Iron would be present mainly as $\mathrm{Fe}^{2+}$ and ferrous sulfide ( $\mathrm{FeS}$ or $\mathrm{FeS}_{2}$ ), and sulfur would be present as $\mathrm{SO}_{4}^{2-}, \mathrm{H}_{2} \mathrm{~S}, \mathrm{HS}^{-}$, and $\mathrm{FeS} / \mathrm{FeS}_{2}$. In the environment illustrated in Figure $11 \mathrm{C}$, the rate of accumulation of organic detritus is so great that the sediments are completely anoxic and reduced, the zero-oxygen isopleth may be some distance above the sediment-water interface, and $\mathrm{H}_{2} \mathrm{~S}$ may accumulate locally in the bottom waters. The extent of deoxygenation of the bottom waters would be controlled by the rate of oxygen consumption, rate of $\mathrm{H}_{2} \mathrm{~S}$ production, rate of oxygen supply to the bottom waters, strength of bottom currents (advection of oxygen), and rate of sedimentation. Sluggish bottom-water circulation and (or) extreme drawdown of oxygen by oxidation of organic carbon in the water column would aid in $\mathrm{H}_{2} \mathrm{~S}$ accumulation and may even be necessary for this to occur, but the primary cause of anoxic conditions would be the high rate of biological oxygen demand within the sediments. Iron would be present as ferrous sulfide (plus some $\mathrm{Fe}^{2+}$ ), sulfur would be present mainly as $\mathrm{SO}_{4}^{2-}$, $\mathrm{H}_{2} \mathrm{~S}, \mathrm{HS}^{-}$, and $\mathrm{FeS}$, and the benthic epi- and infauna would be eliminated. The black color would result mainly from organic matter and FeS. The FeS would eventually be converted to $\mathrm{FeS}_{2}$ (pyrite or marcasite) which would tend to lighten the color of the sediments (Berner, 1970). However, maturation of the organic matter would tend to darken the color of the sediments with the result that the black muds probably would become black, or at least dark gray, shales through increasing thermal alteration and diagenesis. If the initial deposition resulted in interbedding of layers more and less enriched in organic matter but otherwise homogeneous, then migration of $\mathrm{SO}_{4}^{2-}$ into layers enriched in organic matter to replace $\mathrm{SO}_{4}^{2-}$ consumed by sulfate reduction may produce localized concentrations of $\mathrm{FeS}$ and an intensification of color differences (Berner, 1969). With time, these localized sulfide concentrations would produce concentrations of pyrite at the boundary between interbeds of more- and less-organic-carbon-rich mud rocks (Fig. 3).

One problem with this model is how organic-carbon supply to deep-water sediment can increase without creating an excess of production over consumption of organic carbon in the water column. In the modern ocean, it has been shown that less than $0.1 \%$ of the organic carbon produced survives to a depth of $4000 \mathrm{~m}$ or greater (Suess, 1980) because of high rates of consumption and oxidation in the water column. It is therefore unlikely that changes in surface productivity alone could account for organic-carbon enrichment in the black shales without concomitant depletion of dissolved oxygen in the bottom waters. However, enough organic carbon could be supplied periodically to cause interbedding of green and red sediment because such changes in oxidation state are found in Holocene oceanic deepwater sediments (Lynn and Bonatti, 1965; McGeary and Damuth, 1973; Gardner et al., 1982). Presumably the periodicity in initial organic-carbon-preservation would be aided by periodic increases in sedimentation rate (Heath et al., 1977; Müller and Suess, 1979) which could also explain the red and green cycles.

\section{Influences of Turbidity Currents}

The $\mathrm{C}_{\text {org }}$-rich strata in the Atlantic Ocean commonly are interpreted as pelagic sediments that accumulated under anoxic conditions. However, there are now many examples described from DSDP sites which show that turbidity currents have been at least partly responsible for the deposition of some black shales.

In the western North Atlantic, Sites 101 and 105 (Lancelot et al., 1972), 386 and 387 (McCave, 1979a), 391 (Benson, Sheridan, et al., 1978), 417 and 418 (Donnelly et al., 1980), and 534 (Sheridan, Gradstein, et al., 1982) all penetrated mid-Cretaceous black shales. The black shales are interbeded with reddish, greenish, and grayish mudstones and marlstones, and commonly make up less than $50 \%$ of the section. The black shales are variously laminated, massive, and bioturbated, and contain variable concentrations of organic carbon of mixed terrigenous and marine origins (Tissot et al., 1979 and 1980). Fine-grained turbidites make up parts (mainly less than $30 \%$ ) of the mid-Cretaceous section at each site, occurring in both black shales and associated li- 
thologies. There are thin-bedded siltstone and mudstone turbidites, mostly derived from the North American continental margin, as well as thicker-bedded biogenic turbidites, probably derived locally from intrabasin highs. With more detailed analyses, however, the percentage of turbidites may well increase for, as McCave (1979b) found after detailed size analyses of sediments from Sites 386 and 387, "More units in the black and green mudstone sequence may be graded and of possible turbidite origin than at first presumed."

In the eastern North Atlantic off the Euro-African continental margin, Sites 367, 368, 369 and 370 (Dean et al., 1977; Dean and Gardner, 1982), 397 (Cornford, 1979), 398 (Arthur, 1979a), 400 and 402 (de Graciansky et al., 1979), and 415, and 416 (Lancelot, Winterer et al., 1980) also penetrated mid-Cretaceous black shales that show evidence of turbidite deposition. The black shales again form part (usually less than $50 \%$ ) of a more fully oxidized section comprising multicolored mudstones and marlstones. Most of the turbidites recognized are fine-grained siltstone or mudstone, although at Sites $370,397,398,402$, and 416 there are interbedded coarser-grained and thicker-bedded turbidites, debris-flow deposits, and slumped units. There is no consistent association of turbidites with any one particular facies. For example, at Site 398 thin-bedded turbidites grade upward into biogenic pelagic strata, and at Site 400 biogenic calcilutite turbidites grade up into black shales, parts of which may represent pelagic sedimentation.

It appears that the Eocene black clays in the North Atlantic at Sites 367 (Dean et al., 1978; Dean and Gardner, 1982) and 386 (McCave, 1979b) are more consistently fine-grained turbidites that have been redeposited into a fully oxic oceanic basin. They are very similar to some of the Neogene black-shale turbidites in the Mediterranean and Black seas (e.g., Sites 378 and 380, Hsü, Montadert et al., 1978).

At least three DSDP sites in the South Atlantic that have recovered mid-Cretaceous black shales show clear evidence of turbidites. At Site 361 (Natland, 1978; Arthur and Natland, 1979) a sequence of thick sandstone and pebbly sandstone turbidites and slumps are associated with green, gray, and black mudstones. The coarse-grained turbidites commonly are rich in terrigenous organic debris and grade upward into thinly laminated black shales, some of which contain more marine organic matter. Both pelagic and turbiditic processes may have been involved in the deposition of these units. The black shales and associated facies at Sites 364 (Bolli, Ryan et al., 1978) and 530 (Stow and Dean, this volume) have a more distal or basinal character.

From the above discussion it is clear that turbidites commonly are associated with black shales in the Atlantic Ocean. However, they rarely form the dominant part of the section. Some black shales were deposited entirely or partly as thin-bedded siltstone or mudstone turbidites, whereas others were deposited by pelagic processes. Where turbidites do occur in black-shale sequences they provide: (1) a mechanism for periodically increasing the supply of organic matter to sediments; (2) an element of randomness to the cyclicity of $\mathrm{C}_{\text {org }}$-rich and $\mathrm{C}_{\text {org }}$-poor strata, both regionally and temporally; and (3) a means of transporting oxygen-depleted shelf waters to ocean basins and (or) causing bottom-water mixing.

\section{Climatic and Oceanographic Controls}

Turbidity currents and pelagic deposition, operating separately or together, can provide a variable supply of organic-carbon-rich sediment and result in the interbedding of lithologies of varying color and organic content. But why was the supply of organic debris so much greater during the middle Cretaceous? Local pockets of accumulation of organic matter in continental margin areas today are the result of local circulation patterns (e.g., Walvis Bay, southwest Africa; Santa Barbara Basin, southern California). It is unlikely that such conditions would have existed around the entire margin of the Early to middle Cretaceous Atlantic Ocean as well as on isolated plateaus and seamounts in the Pacific (Schlanger and Jenkyns, 1976; Dean et al., 1981; Thiede et al., 1982) without the aid of some worldwide conditions of ocean circulation and productivity. Global climate during the Early to middle Cretaceous was warm, eustatic sea levels were high, spreading rates were fast, pelagic sediments in the world ocean were accumulating rapidly, and oceanic surface- and bottom-water temperatures were high (Douglas and Savin, 1975; Fischer and Arthur, 1977; Brass et al., 1982). Increased surface-water temperatures would have had two main effects: first, thermohaline deep-water circulation, driven today by the sinking of cold, oxygen-rich surface waters in high latitudes, would have been more sluggish; and second, the warmer water would contain lower concentrations of dissolved oxygen. Bottom-water circulation was sufficient to supply some oxygen to maintain oxidizing conditions in the deep basins of the Pacific but slow enough to permit depletion of dissolved oxygen at mid-water depths in areas of high productivity of organic matter. Accumulations of organic-carbon-rich sediments at many places in the world ocean at times that were not always strictly synchronous undoubtedly are the results of coincidences of several factors acting to produce and preserve organic matter. During the middle Cretaceous, much of the world ocean may have been so poised that relatively small changes in the flux of organic matter and (or) circulation at any one place may have caused anoxia or near-anoxia within midwater oxygenminimum zones and possibly, under extreme conditions, throughout much of the bottom-water mass. An expanded and intensified oxygen minimum would explain the excellent preservation of organic carbon, and the increase in accumulation rate of organic carbon over a much larger area in slope and deep-sea (largely by redeposition) environments during much of the Early and middle Cretaceous. It is not inconceivable that the intensified oxygen-minimum zone extended as deep as 2500 to $3000 \mathrm{~m}$; this would help to explain the presence of Albian black shales containing well-preserved organic carbon on or near the crest of the Mid-Atlantic Ridge in the North Atlantic (Sites 386 and 417/418) where it is 
unlikely that continental-margin-derived turbidites could have supplied all of the organic matter.

\section{Interrelationship of Variables}

From the above discussion, it is apparent that the origin of interbedded more- and less-reduced lithologies with variable amounts of organic matter and variable amounts of pelagic, hemipelagic, and terrigenous sediment is complex and probably is not the result of any one simple process. In Figure 12 we have attempted to show a range of variables that may have operated during a period of time when less organic matter was accumulating (Fig. 12A; e.g., Albian-Cenomanian), in contrast with a period of time when more organic matter was accumulating (Fig. 12B; Aptian-Albian or Cenomanian-Turonian). The main variables are the rate of influx of terrigenous sediment and organic matter, and surface-water productivity. The amounts of organic matter from these two sources (terrestrial and marine) in turn determine the thickness and intensity of a midwater oxygen minimum zone. Surface-water productivity is determined, at least in part, by the intensity of upwelling of nutrient-rich water from the oxygen-minimum zone. Other variables are the frequency and magnitude of turbidity currents, as well as climatic, oceanographic, and paleogeographic conditions.

In the situation shown diagrammatically in Figure $12 \mathrm{~A}$, surface-water productivity is fairly high so that there is a mid-water oxygen minimum. Shelf sediments would consist largely of terrigenous clastic material and organic matter with some contributions from autochthonous marine organic matter and biogenic calcareous and siliceous debris. Sediment that accumulated where the continental margin intersected the oxygen minimum might be organic-carbon-rich, black, and laminated if the dissolved oxygen concentration was near zero throughout a sufficient thickness of the water column. The composition or any redeposited sediment would depend on local sources. Slope sediments along arid continental margins that are characterized by coastal upwelling would be primarily fine grained and rich in carbonate or biogenic silica (e.g., Sites 398, 400, 402, and 370). Sediment accumulating in well-oxygenated bottom-water environments would be mostly red clay. Occasionally, there would be green clay interbeds that represent periods of accumulation of slightly higher concentrations of organic matter, high enough to consume all of the dissolved oxygen within the sediment and to impart a green color (mainly from reduced iron) to the sediment, but not enough to have a marked effect on the benthic fauna. The result would be interbedded red and green clay units that are both intensely bioturbated.

In the situation shown diagrammatically in Figure $12 \mathrm{~B}$, there is higher surface-water productivity in response to a greater supply of nutrients from more intense upwelling. In addition, there may be an increase in the influx of terrestrial organic matter as a result of a rise in sea level and (or) an increase in amount of terrestrial vegetation. This increased supply of organic matter from marine and/or terrestrial sources would increase the oxygen demand in the water column and in
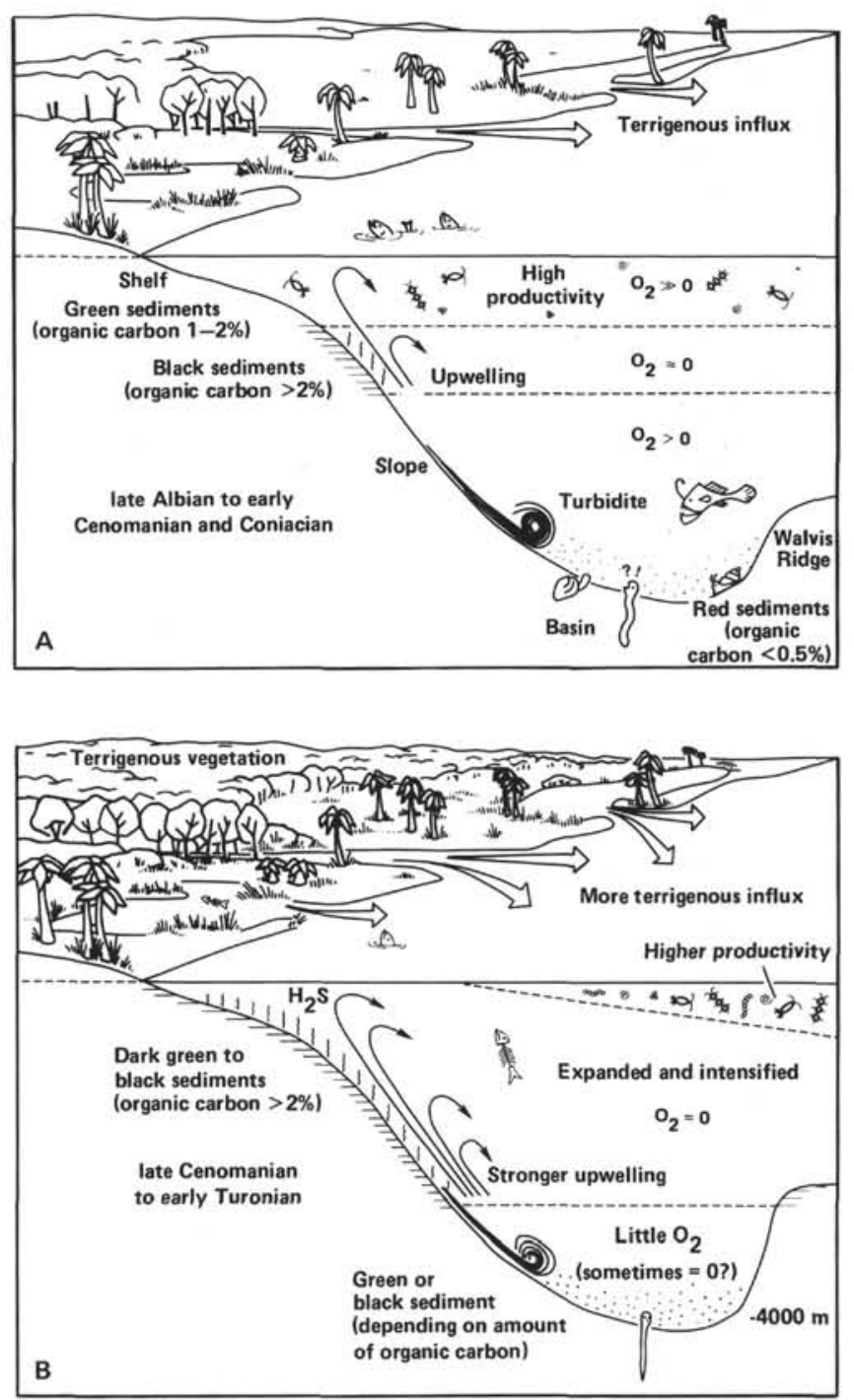

Figure 12. Illustrations showing how influx of terrigenous organic matter, surface-water organic productivity, upwelling, and turbidity currents may contribute to accumulation and redeposition of sediments containing varying amounts of organic carbon and, therefore, ranging in color from red to black. A. Example of a period of moderate supply of organic detritus from autochthonousmarine and terrigenous sources and moderate upwelling resulting in accumulation of green sediment in shelf areas, sediment with high organic-carbon concentrations, perhaps black in color, within the $\mathrm{O}_{2}$-minimum zone, and dominantly red clays in the deep basin. Such conditions might be representative of the Late Cretaceous (e.g., Santonian-Coniacian) in the Atlantic Ocean. B. Example of a period of rapid rate of supply of organic detritus and stronger upwelling resulting in an expanded and more intense $\mathrm{O}_{2}$-minimum zone that may include much of the water mass and allow organiccarbon-rich sediment to accumulate over a much greater area and provide a greater source area for supply of organic-carbon-rich sediment to the deep basin by downslope transport. Such conditions might be representative of periods of accumulation of organic-carbon-rich strata in the Atlantic Ocean (Aptian-Albian and Cenomanian-Turonian).

the sediments which would cause an expansion and intensification of the oxygen minimum zone. As a result, sediment accumulating along the continental margin would be more reduced and contain higher concentra- 
tions of organic matter, and this sediment would cover a much greater area. Because there would be more sediment containing higher concentrations of organic matter available for down-slope transport into deeper-water environments, the basin sediment also would be more reduced and contain higher concentrations of organic matter. In extreme cases, when bottom waters were delicately poised at a low oxygen level, oxygen-deficient conditions may have extended into deeper waters, but most of the time the bottom-water mass was sufficiently oxic to support at least a benthic epifauna. The resulting sediment facies would consist of dark green to black, organic-carbon-rich sediment deposited in continentalmargin settings, and interbedded green and black, organic-carbon-rich basinal sediment. Sediment deposited in either the continental margin or basinal environments at times of extreme oxygen deficiency might be laminated, indicating complete elimination of the benthic fauna.

We believe that a complex interrelationship of processes of the sort outlined above is the most appropriate model for black-shale accumulation at Site 530 as well as in many other parts of the Atlantic during the Early to middle Cretaceous. The most important process for any one area or bed is difficult if not impossible to resolve, and the extent to which different processes operated most likely varied at different times and places.

The diagenetic redox cycles of variable duration $(20,000$ to 140,000 years on average) and their color manifestations are superimposed on a longer period cyclicity that has resulted in three periods of maximum accumulation of organic carbon in the Cretaceous Atlantic Ocean-the Neocomian, the Aptian-Albian, and the Cenomanian-Turonian. Unfortunately, we know little about the periodicity of the main variables involved; these variables are as follows:

1) Variation in bottom-water oxygenation (influenced by climatic, oceanographic, and paleogeographic factors). Low oxygen levels are inferred for much of the Early to middle Cretaceous, and periods of lowest oxygen may correspond to the three periods of maximum accumulation of organic carbon.

2) Variation in the extent and intensity of a midwater oxygen minimum (influenced by climatic and oceanographic effects on surface productivity and vertical mixing). An expanded oxygen minimum is inferred for the periods of maximum accumulation of organic carbon, but probably there were shorter-period variations in the extent and intensity of the oxygen minimum as well.

3) Variation in the supply of organic matter to sediments (influenced by surface productivity, terrestrial supply, and redeposition processes). The supply of organic matter probably had a complex and irregular periodicity, in part following that of surface productivity.

The preservation of organic carbon in the sediment and the development of black, green, or red coloration depends therefore on the interrelationships of these three main variables in a way similar to that suggested by Tucholke and Vogt (1979). It is not surprising, therefore, that the cyclicity, organic-carbon content, and depositional characteristics of middle Cretaceous black shales in the Atlantic are so variable.

\section{CONCLUSIONS}

1. Most of the Cretaceous section in the Atlantic Ocean is characterized by an interbedding of more-reduced and less-reduced lithologies, most commonly red and green or green and black mudstones and marlstones. The black lithologies usually contain more than $2 \%$ organic carbon and commonly contain more than $10 \%$ organic carbon.

2. Most of the organic matter in organic-carbon-rich Cretaceous strata in the western and northern North Atlantic Ocean is of terrestrial origin, whereas most of the organic matter in equivalent strata in the southeastern North Atlantic and South Atlantic is of marine origin. Mixtures of terrestrial and marine organic matter, however, are common in both the North and South Atlantic.

3. Periodicities of the redox cycles usually range between 20,000 and 100,000 years/cycle and average about 40,000 to 50,000 years/cycle. These cycles may be responses to climatic forcing, similar to Cenozoic climateinduced depositional cycles, but they may also reflect, in part, periodic sediment redeposition events.

4. Certain trace elements, especially $\mathrm{Cd}, \mathrm{Cu}, \mathrm{Zn}$, $\mathrm{Mo}, \mathrm{V}, \mathrm{Ni}$, and $\mathrm{Cr}$, are enriched in organic-carbon-rich strata. This trace-element enrichment may be the result of concentration by clays and organic matter and coprecipitation with sulfide minerals under reducing conditions. The enrichments may reflect deposition of sediment under anoxic conditions in the deep sea, or may be inherited from original deposition under low-oxygen conditions upslope and subsequent redeposition to oxygenated deeper-water environments.

5. Compactional dewatering of some black-shale sequences resulted in upward diffusion of some reduced metal ions after deposition of high concentrations of organic matter and resulting anoxic conditions within the sediment. Slowly deposited, oxidized claystones overlying some black-shale sequences are enriched in some metals, particularly $\mathrm{Fe}, \mathrm{Mn}, \mathrm{Zn}$, and $\mathrm{Cu}$, relative to normal pelagic clays, and this enrichment may be the result of upward migration of metals from the underlying black shale.

6. The origin of interbedded more- and less-reduced lithologies containing varying amounts of organic matter and varying amounts of pelagic, hemipelagic, and terrigenous sediment is complex and probably is not the result of any one process. The main variables are the rate of influx of terrigenous sediment and organic matter, and surface-water productivity. Variations in rate of supply of these two sources of organic matter from shallow-water areas to deeper, basinal sites of accumulation, produced cyclic interbeds of more-reduced and less-reduced lithologies. During several periods of time (e.g., Neocomian, Aptian-Albian, and CenomanianTuronian), a coincidence of several climatic and oceanographic factors apparently resulted in maximum production and preservation of organic matter in deepsea environments that otherwise were fairly well oxygenated and were preserving lesser amounts of organic 
matter. Bottom water anoxia may have occurred during these periods of maximum accumulation of organiccarbon-rich strata, but the commonly observed cyclic interbeds of green and black strata are in part also the result of diagenetic fluctuations in redox potential in the sediment in response to fluctuation in amount of organic debris being deposited, regardless of source. At times, much of the organic debris was transported to basinal sites from continental-margin settings within oxygenminimum zones by turbidity currents; at other times, the organic debris was largely of pelagic origin.

\section{ACKNOWLEDGMENTS}

We would like to thank Joseph Hatch, Douglas Kirkland, Philip Meyers, Harry Tourtelot, and Douglas Waples for helpful reviews of the manuscript. Louise Reif was particularly helpful in massaging several long drafts of the manuscript through the word processor.

\section{REFERENCES}

Anderson, T. F., Arthur, M. A., and Holzer, W. T., 1982. Organic carbon and sulfur in black shales and secular variations in $\delta^{13} \mathrm{C}$ and $\delta^{34}$ S. Geol. Soc. Am. Abstract with Programs, 14(7):433. (Abstract)

Arthur, M. A., 1979a. North Atlantic Cretaceous black shales: The record at Site 398 and a brief comparison with other occurrences. In Sibuet, J.-C., Ryan, W. B. F., et al., Init. Repts. DSDP, 47, Pt. 2: Washington (U.S. Govt. Printing Office), 719-751. $1979 \mathrm{~b}$. Origin of Upper Cretaceous multicolored claystones of the western Atlantic. In Tucholke, B. E., Vogt, P. R., et al., Init. Repts. DSDP, 43: Washington (U.S. Govt. Printing Office), 417-420.

1982. The carbon cycle-Controls on atmospheric $\mathrm{CO}_{2}$ and climate in the geologic past. In Berger, W. H., and Crowell, J. C. (Eds.), Pre-Pleistocene Climates: Washington (National Acad. Sci.-National Res. Council Geophys. Study Group Public.)

Arthur, M. A., and Fischer, A. G., 1977. Upper Cretaceous-Paleocene magnetic stratigraphy at Gubbio, Italy: I. Lithostratigraphy and sedimentology. Geol. Soc. Am. Bull., 88:367-389.

Arthur, M. A., and Natland, J. H., 1979. Carbonaceous sediments in the North and South Atlantic: The role of salinity in stable stratification of early Cretaceous basins. In Talwani, M., Hay, W. W., and Ryan, W. B. F. (Eds.), Deep Drilling Results in the Atlantic Ocean: Continental Margins and Paleoenvironment: Washington (Am. Geophys. Union, Maurice Ewing Series), 3:375-401.

Arthur, M. A., and Schlanger, S. O., 1979. Cretaceous "oceanic anoxic events" as causal factors in development of reef-reservoired giant oilfields. Bull. Am. Assoc. Petrol. Geol., 63:870-885.

Barker, P. F., Dalziel, I. W. D., et al., 1977. Init. Repts. DSDP, 36: Washington (U.S. Govt. Printing Office).

Baturin, G. N., 1972. Phosphorus in interstitial waters of sediments of the southeastern Atlantic. Oceanology, 12:849-855.

Baturin, G. N., Kochenov, A. V., and Petelin, V. P., 1970. Phosphorite formation on the shelf of Southwest Africa: Lithol. Miner. Resour., 3:266-276.

Benson, W. E., Sheridan, R. E., et al., 1978. Init. Repts. DSDP, 44: Washington (U.S. Govt. Printing Office).

Berner, R. A., 1969. Migration of iron and sulfur within anaerobic sediments during early diagenesis. $A m$. J. Sci., 267:19-42. 1-23.

1970. Sedimentary pyrite formation. Am. J. Sci., 268:

1971. Principles of Chemical Sedimentology: New York (McGraw-Hill).

1974. Kinetic models for the early diagenesis of nitrogen. sulfur, phosphorus, and silicon in anoxic marine sediments. In Goldberg, E. D. (Ed.), The Sea (Vol. 5), Marine Chemistry: New York (John Wiley), pp. 427-449.

1975. Diagenetic models of dissolved species in the interstitial waters of compacting sediments. Am. J. Sci., 275:88-96.

1978. Sulfate reduction and the rate of deposition of marine sediments: Earth Planet. Sci. Lett., 37:492-498.
1980. Early Diagenesis-A Theoretical Approach: Princeton (Princeton University Press).

Bolli, H. M., Ryan, W. B. F., et al., 1978. Init. Repts. DSDP, 40: Washington (U.S. Govt. Printing Office).

Boyle, R. W., and Lynch, J. J., 1968. Speculations on the source of zinc, cadmium, lead, copper, and sulfur in Mississippi Valley and similar types of lead-zinc deposits. Econ. Geol. 63:421-422.

Boström, K., Joensuu, O., and Brohm, I., 1974. Plankton: Its composition and its significance as a source of pelagic sediments. Chem. Geol., 14:255-271.

Brass, G. W., Southam, J. R., and Peterson, W. H., 1982. Warm saline bottom water in the ancient ocean. Nature, 296:620-623.

Brewer, P. G., and Spencer, D. W., 1974. Distribution of some trace elements in Black Sea and their flux between dissolved and particulate phases. In Degens, E. T., and Ross, D. A. (Eds.), The Black Sea-Geology, Chemistry and Biology (Am. Assoc. Petrol. Geol. Mem.), 20:137-143.

Brongersma-Sanders, M., 1965. Metals of Kupferschiefer supplied by normal seawater. Geol. Rundschau, 55:365-375.

Brongersma-Sanders, M., Stephan, K. M., Kwee, T. G., and de Bruin, M., 1980. Distribution of minor elements in cores from the Southwest Africa shelf with notes on plankton and fish mortality. Mar. Geol., 37:91-132.

Bruland, K. W., 1980. Oceanographic distributions of cadmium, zinc, nickel, and copper in the North Pacific. Earth Planet. Sci. Lett., 47:176-198.

Brumsack, H. J., 1980. Geochemistry of Cretaceous black shales from the Atlantic Ocean (DSDP Legs 11, 14, 36, and 41). Chem. Geol., 31:1-25.

Calvert, S. E., 1976. The mineralogy and geochemistry of nearshore sediments. In Riley, J. P., and Chester, R. (Eds.), Chemical Oceanography (Vol. 6): New York (Academic Press), pp. 187-280.

Calvert, S. E., and Price, N. B., 1970. Minor metal contents of recent organic-rich sediment off South West Africa. Nature, 227: 593-595.

Chester, R., and Aston, S. R., 1976. Geochemistry of deep-sea sediments. In Riley, J. P., and Chester, R. (Eds.), Chemical Oceanog raphy, (Vol. 6): New York (Academic Press), pp. 281-390.

Chester, R., Griffiths, A., and Stoner, J. H., 1978. Minor metal content of surface seawater particulates and organic-rich shelf sediments. Nature, 275:308-309.

Cornford, C., 1979. Organic deposition at a continental rise: organic geochemical interpretation and synthesis at Site 397, Eastern North Atlantic. In von Rad, U., Ryan, W. B. F., et al., Init. Repts. DSDP, 47A: Washington (U.S. Govt. Printing Office), 503-510.

Curtis, C. D., 1980. Diagenetic alteration in black shales. J. Geol. Soc. London, 137:189-194.

Dean, W. E., Gardner, J. V., Jansa, L. F., Ćepek, P., Seibold, E., 1978. Cyclic sedimentation along the continental margin of northwest Africa. In Lancelot, Y., Seibold, E., et al., Init. Repts. DSDP, 41: Washington (U.S. Govt. Printing Office), 965-986.

Dean, W. E., and Gardner, J. V., 1982. Origin and geochemistry of redox cycles of Jurassic to Eocene age, Cape Verde Basin (DSDP Site 367), continental margin of northwest Africa. In Schlanger, S. O., and Cita, M. B. (Eds.), Nature and Origin of Cretaceous Organic Carbon-Rich Facies: London (Academic Press) pp. 55-78.

Dean, W. E., Claypool, G. E., and Thiede, J., 1981. Origin of organic carbon-rich mid-Cretaceous limestones, mid-Pacific mountains and southern Hess-Rise. In Thiede, J., Vallier, T. L., et al., Init. Repts. DSDP, 62: Washington (U.S. Govt. Printing Office), $877-890$.

Demaison, G. J., and Moore, G. T., 1980. Anoxic environments and oil source bed genesis. Bull. Am. Assoc. Petrol. Geol., 64: 1179-1209.

Degens, E. T., and Stoffers, P., 1976. Stratified waters as a key to the past. Nature, 263:22-27.

de Graciansky, P. C., Auffret, G. A., Dupeuble, P., Montadert, L., and Muller, C., 1979. Interpretation of depositional environments of the Aptian-Albian black shales on the north margin of the Bay of Biscay (DSDP Sites 400 and 402). In Montadert, L., Roberts, D. G., et al., Init. Repts. DSDP, 49: Washington (U.S. Govt. Printing Office), 877-907.

de Graciansky, P. C., and Chenet, 1979. Sedimentological study of Cores 138 to 56 (upper Hauterivian to middle Cenomanian): An 
attempt at reconstruction of paleoenvironments. In Sibuet, J.-C., Ryan, W. B. F., et al., Init. Repts. DSDP, 47, Pt 2: Washington (U.S. Govt. Printing Office), 403-418.

Deuser, W. G., 1974. Evolution of anoxic conditions in the Black Sea during the Holocene. In Degens, E. T., and Ross, D. A. (Eds.), The Black Sea-Geology, Chemistry and Biology (Am. Assoc. Petrol. Geol. Mem.), 20:133-136.

Didyk, B. M., Simoneit, B. R. T., Brassell, S. C., and Eglinton, G., 1978. Geochemical indicators of paleoenvironmental conditions of sedimentation: Nature, 272:216-222.

Donnelly, T. W., 1980. Chemical composition of deep sea sedimentsSite 9 through 32, Legs 52 through 54, Deep Sea Drilling Project. In Rosendahl, B. R., Hekinian, R., et al., Init. Repts. DSDP, 54: Washington (U.S. Govt. Printing Office), 899-949.

Douglas, R. G., and Savin, S. M., 1975. Oxygen and carbon isotope analyses of Tertiary and Cretaceous microfossils from Shatsky Rise and other sites in the North Pacific Ocean. In Larson, R. L., Moberly, R., et al., Init. Repts. DSDP, 32: Washington (U.S. Govt. Printing Office), 509-521.

Ekdale, A. A., 1980. Trace fossils and stagnation of deep-sea basins. Bull. Am. Assoc. Petrol. Geol., 64:704. (Abstract)

Elderfield, H., 1981. Metal-organic associations in interstitial waters of Narragansett Bay sediments. Am. J. Sci., 281:1184-1196.

Fischer, A. G., and Arthur, M. A., 1977. Secular variations in the pelagic realm. In Cook, H. E., and Enos, P. (Eds.), Deep Water Carbonate Environments (Soc. Econ. Paleontol. Mineral. Spec. Publ.), 25:19-50.

Froelich, P. N., Bender, M. L., Luedtke, N. A., Heath, G. R., and de Vries, T., 1982. The marine phosphorus cycle. Am. J. Sci., 282: 474-511.

Froelich, P. N., Klinkhammer, G. P., Bender, M. L., Luedtke, N. A., Heath, G. R., Cullen, D., Dauphin P., Hammond, D., Hartman, B., and Maynard, V., 1979. Early oxidation of organic matter in pelagic sediments of the eastern equatorial Atlantic: Suboxic diagenesis. Geochem. Cosmochim. Acta, 43:1075-1090.

Gardner, J. V., Dean, W. E., and Jansa, L. F., 1978. Sediments recovered from the northwest African continental margin, Leg 41, DSDP. In Lancelot, Y., Seibold, E., et al., Init. Repts. DSDP, 41: Washington (U.S. Govt. Printing Office), 1121-1134.

Gardner, J. V., Dean, W. E., Klise, D. H., and Baldauf, J. G., 1982. A climate-related oxidizing event in deep-sea sediment from the Bering Sea. Quat. Res., 18:91-107.

Glenn, C., and Arthur, M. A., 1982. Deposition of black shales and the cycling of oceanic phosphate. Geol. Soc. Am. Abstract with Programs, 14(7):497. (Abstract)

Goldberg, E. D., 1957. Biogeochemistry of trace metals. In Hedgepeth, J. W. (Ed.), Treatise on Marine Ecology and Paleoecology (Vol. 1), Ecology. Geol. Soc. Am. Mem., 67:345-357.

Goldhaber, M. B., and Kaplan, I. R., 1974. The sulfur cycle in the sea. In Goldberg, E. D. (Ed.), The Sea (Vol. 5), Marine Chemistry: New York (John Wiley) 569-655.

1975. Controls and consequences of sulfate reduction rates in recent marine sediments. Soil Sci., 119:42-55.

1980. Mechanisms of sulfur incorporation and isotope fractionation during early diagenesis in sediments of the Gulf of California. Mar. Chem., 9:95-143.

Goldhaber, M. B., Aller, R. C., Cochran, J. K., Rosenfeld, J. K., Martens, C. S., and Berner, R. A., 1977. Sulfate reduction, diffusion, and bioturbation in Long Island Sound sediments: Report of the Foram Group. Am. J. Sci., 277:193-237.

Heath, G. R., Moore, T. C., and Dauphin, J. P., 1977. Organic carbon in deep-sea sediments. In Anderson, N. R., and Malahoff, A. (Eds.), The Fate of Fossil Fuel $\mathrm{CO}_{2}$ in the Oceans: New York (Plenum Press), pp. 605-625.

Hirst, D. M., 1974. Geochemistry of sediments from eleven Black Sea cores. In Degens, E. T., and Ross, D. A., (Eds.), The Black Sea-Geology, Chemistry and Biology (Am. Assoc. Petrol. Geol. Mem.), 20:430-455.

Holland, H. D., 1979. Metals in black shales-A reassessment. Econ. Geol., 74:1676-1680.

Hsü, K. J., Montadert, L., et al., 1978. Init. Repts. DSDP, 42, Pt. 1: Washington (U.S. Govt. Printing Office).

Ibach, L. E. J., 1982. Relationship between sedimentation rate and total organic carbon content in ancient marine sediments. $\mathrm{Am}$. Assoc. Petrol. Geol. Bull., 66:170-188.
Jansa, L. F., Gardner, J. V., and Dean, W. E., 1978. Mesozoic sequences of the central North Atlantic. In Lancelot, Y., Seibold, E., et al., Init. Repts. DSDP, 41: Washington (U.S. Govt. Printing Office), 991-1031.

Jansa, L. F., Enos, P., Tucholke, B. E., Gradstein, F. M., and Sheridan, R. E., 1979. Mesozoic-Cenozoic sedimentary formations of the North Atlantic basin; western North Atlantic. In Talwani, M., Hay, W. W., and Ryan, W. B. F., (Eds), Deep Drilling Results in the Atlantic Ocean: Continental Margins and Paleoenvironment: Am. Geophys. Union, Maurice Ewing Series, 3:1-57.

Jorgensen, B. B., 1977. The sulfur cycle of a coastal marine sediment (Limfjorden, Denmark). Limnol. Oceanog., 22:814-832.

Keller, G. H., 1974. Mass physical properties of some western Black Sea sediments. In Degens, E. T., and Ross, D. A., (Eds.), The Black Sea-Geology, Chemistry, and Biology (Am. Assoc. Petrol. Geol. Mem.), 20:332-337.

Kelts, K., and Arthur, M. A., 1981. Turbidites after ten years of Deep Sea Drilling - Wringing out the mop? In Warme, J. E., Douglas, R. G., and Winterer, E. L. (Eds.), The Deep Sea Drilling Project: A Decade of Progress (Society of Economic Paleontologists and Mineralogists Spec. Publ.), 32:91-127.

Kendrick, J. W., 1979. Geochemical studies of black clays from Leg 43, Deep Sea Drilling Project. In Tucholke, B., Vogt, P., et al., Init. Repts. DSDP, 43: Washington (U.S. Govt. Printing Office), 633-642.

Knauer, G. A., and Martin, J. H., 1973. Seasonal variations of cadmium, copper, manganese, lead, and zinc in water and phytoplankton in Monterey Bay, California. Limnol. Oceanog., 18: 597-604.

Lancelot, Y., Hathaway, J. C., and Hollister, C. D., 1972. Lithology of sediments from the western North Atlantic, Leg 11, Deep Sea Drilling Project. In Hollister, C. D., Ewing, J. I., et al., Init. Repts. DSDP, 11: Washington (U.S. Govt. Printing Office), 901-950.

Lancelot, Y., Seibold, E., et al., 1978. Init. Repts. DSDP, 41: Washington (U.S. Govt. Printing Office).

Lancelot, Y., Winterer, E. L., et al., 1980. Init. Repts. DSDP, 50: Washington (U.S. Govt. Printing Office).

Lange, J., Wedepohl, K. H., Heinrichs, H., and Gohn, E., 1978. Notes about the specific chemical composition of "black shales" from Site 367 (Leg 41). In Lancelot, Y., Seibold, E., et al., Init. Repts. DSDP, 41: Washington (U.S. Govt. Printing Office), 875-877.

Leinen, M., and Stakes, D., 1979. Metal accumulation rates in the central equatorial Pacific during Cenozoic time. Geol. Soc. Am. Bull., 90:357-375.

Levanthal, J. S., 1983. An interpretation of carbon and sulfur relationships in Black Sea sediments as indicators of environments of deposition. Geochim. Cosmochim. Acta, 47:133-137.

Lynn, D. C., and Bonatti, E., 1965. Mobility of manganese in diagenesis of deep-sea sediments. Mar. Geol., 3:457-474.

Manheim, F. T., 1961. A geochemical profile in the Baltic Sea. Geochim. Cosmochim. Acta, 25:52-71.

Martin, J. H., and Knauer, G. A., 1973. The elemental composition of plankton. Geochim. Cosmochim. Acta, 37:1639-1653.

McCave, I. N., 1979a. Depositional features of organic black and green mudstones at DSDP Sites 386 and 387, western North Atlantic. In Tucholke, B. E., Vogt, P. R., et al., Init. Repts. DSDP, 43: Washington (U.S. Govt. Printing Office), 411-416.

McCave, I. N., 1979b. Diagnosis of turbidites at Sites 386 and 387 by partical-counter size analysis of the silt $(2-40 \mu \mathrm{m})$ fraction. In Tucholke, B. E., Vogt, P. R., et al., Init. Repts DSDP, 43: Washington (U.S. Govt. Printing Office), 395-405.

McCoy, F. W., and Zimmerman, H. B., 1977. A history of sediment lithofacies in the South Atlantic Ocean. In Perch-Nielson, K., Supko, P., et al., Init. Repts. DSDP, 39: Washington (U.S. Govt. Printing Office), 1047-1079.

McGeary, D. F. R., and Damuth, J. E., 1973. Postglacial iron-rich crusts in hemipelagic deep-sea sediment. Geol. Soc. Am. Bull., 84, 1201-1212.

Moore, C., and Bostrom, K., 1978, The elemental composition of lower marine organisms. Chem. Geol., 23:1-9.

Morris, K. A., 1979. A classification of Jurassic marine shale sequences: An example from the Toarcian (Lower Jurassic) of Great Britain. Paleogeog., Paleoclimatol., Paleoecol., 26:117-120. 
Müller, P. S., and Suess, E., 1979. Productivity, sedimentation rate, and sedimentary organic carbon content in the oceans. Deep-Sea Res., 26:1347-1362.

Nissenbaum, A., Presley, B. J., and Kaplan, I. R., 1972. Early diagenesis in a reducing fjord, Saanich, Inlet, British Columbia-I. Chemical and isotopic changes in major components of interstitial water: Geochim. Cosmochim. Acta, 36:1007-1027.

Oremland, R. S., and Taylor, B. F., 1978. Sulfate reduction and methanogenesis in marine sediments. Geochim. Cosmochim. Ac$t a, 42: 209-214$.

Parrish, J. T., and Curtis, R. L., 1982. Atmospheric circulation, upwelling, and organic-rich rocks in the Mesozoic and Cenozoic. Palaeogeog., Palaeoclimatol. Palaeoecol. 4:31-66.

Pederson, T. F., and Price, N. B., 1982. The geochemistry of manganese carbonate in Panama Basin sediments. Geochim. Cosmochim. Acta, 46:59-68.

Presley, B. J., Kolodny, Y., Nissenbaum, A., Kaplan, I. R., 1972. Early diagenesis in a reducing fjord, Saanich Inlet, British Columbia-II. Trace element distribution in interstitial water and sediment: Geochim. Cosmochim. Acta, 36:1073-1090.

Price, N. B., and Calvert, S. E., 1977. The contrasting behaviours of iodine and bromine in Recent sediments from the Namibian shelf. Geochim. Cosmochim. Acta, 41:1769-1775.

Redfield, A. C., 1958. The biological control of chemical factors in the environment. Am. Sci., 46:206-226.

Rhoads, D. C., 1973. The influence of bottom-feeding benthos on water turbidity and nutrient recycling. Am. J. Sci., 273:1-22.

Rhoads, D. C., and Morse, J. W., 1971. Evolutionary and ecologic significance of oxygen-deficient marine basins. Lethaia, 4: 413-428.

Ross, D. A., and Degens, E. T., 1974. Recent sediments of Black Sea. In Degens, E. T., and Ross, D. A. (Eds.), The Black Sea-Geology, Chemistry, and Biology (Am. Assoc. Petrol. Geol. Mem.), 20:183-199.

Ryan, W. B. F., and Cita, M. B., 1977. Ignorance concerning episodes of ocean-wide stagnation. Mar. Geol., 23:197-215.

Schlanger, S. O., and Jenkyns, H. C., 1976. Cretaceous oceanic anoxic events-Causes and consequences. Geol. Mijnbouw, 55:179-184.

Scholle, P. A., and Arthur, M. A., 1976. Carbon-isotope fluctuations in Upper Cretaceous sediments: An indicator of paleo-oceanic circulation. Geol. Soc. Am. Abstracts with Programs, 8:1089. (Abstract).

1980. Carbon isotopic fluctuations in pelagic limestones; potential stratigraphic and petroleum exploration tool: $A m$. Assoc. Petrol. Geol.; 64:67-87.

Sclater, J. G., Hellinger, S., and Tapscott, C., 1977. The paleobathymetry of the Atlantic Ocean from the Jurassic to the present. $J$. Geol., 85:509-552.

Sheridan, R. E., Gradstein, F. M., and Shipboard Scientific Party, 1982. Early history of the Atlantic Ocean and gas hydrates on the Blake Outer Ridge: Results of Deep Sea Drilling Project Leg 76. Geol. Soc. Am. Bull., 93:876-885.

Sholkovitz, E., 1973. Interstitial water chemistry of the Santa Barbara Basin sediments. Geochim. Cosmochim. Acta, 37:2043-2073.

Southam, J. R., Peterson, W. H., and Brass, G. W., 1982. Dynamics of anoxia. Palaeogeog., Palaeoclimatol., Palaeoecol., 40:183-198.

Spencer, D. W., Brewer, P. G., and Sachs, P. L., 1972. Aspects of the distribution and composition of suspended matter in the Black Sea. Geochim. Cosmochim. Acta, 36:71-86.

Suess, E., 1976. Nutrients near the depositional interface. In McCave, I. N., (Ed.), The Benthic Boundary Layer: New York, (Plenum Press), pp. 57-79.

1979. Mineral phases formed in anoxic sediments by microbial decomposition of organic matter. Geochim. Cosmochim. Acta, 43:339-352.

1980. Particulate organic carbon flux in the ocean-Surface productivity and oxygen utilization. Nature, 288:260-263.

1981. Phosphate regeneration from sediments of the Peru continental margin by dissolution of fish debris. Geochim. Cosmochim. Acta, 45:577-588.
Summerhayes, C. P., 1981. Organic facies of middle Cretaceous black shales in deep North Atlantic. Am. Assoc. Petrol. Geol., 65: 2364-2380.

Thiede, J., Dean, W. E., and Claypool, G. E., 1982. Oxygen deficient depositional paleoenvironments in the mid-Cretaceous tropical and subtropical central Pacific Ocean. In Schlanger, S. O., and Cita, M. B. (Eds.), Nature and Origin of Cretaceous Organic Carbon-Rich Facies: London (Academic Press), pp. 79-100.

Thiede, J., and Rea, D. K., 1981. Mass accumulation rates of Barremian to Recent biogenic sediments from the Mid-Pacific Mountains (Deep Sea Drilling Project Site 463) and Hess Rise (Sites 464, 465, and 466), Central North Pacific Ocean. In Thiede, J., Vallier, T. L., et al., Init. Repts. DSDP, 62: Washington (U.S. Govt. Printing Office), 637-652.

Thiede, J. and van Andel, Tj. H., 1977. The paleoenvironment of anaerobic sediments in the late Mesozoic South Atlantic Ocean. Earth Planet. Sci. Lett., 33:301-309.

Thierstein, H. R., 1979. Paleooceanographic implications of organic carbon and carbonate distribution in Mesozoic deepsea sediments. In Talwani, M., Hay, W. W., and Ryan, W. B. F. (Eds.), Deep Drilling Results in the Atlantic Ocean: Continental Margins and Paleoenvironment: Washington (Am. Geophys. Union, Maurice Ewing Series), 3:249-274.

Tissot, B., Demaison, G., Masson, P., Delteil, J. R., and Combaz, A., 1980. Paleoenvironment and petroleum potential of middle Cretaceous black shales in Atlantic basins. Bull. Am. Assoc. Petrol. Geol., 64:2051-2063.

Tissot, B., Deroo, G., and Herbin, J. P., 1979. Organic matter in Cretaceous sediments of the North Atlantic: Contributions to sedimentology and paleogeography. In Talwani, M., Hay, W., and Ryan, W. B. F. (Eds.), Deep Drilling in the Atlantic Ocean: Continental Margins and Paleoenvironment (Am. Geophys. Union, Maurice Ewing Series), 3:362-374.

Tissot, B., Durand, B., Espitalié, and Combaz, A., 1974. Influence of nature and diagenesis of organic matter in formation of petroleum: Am. Assoc. Petrol. Geol. Bull., 58:499-506.

Toth, D. J., and Lerman, A., 1977. Organic matter reactivity and sedimentation rates in the ocean. Am. J. Sci., 277:465-485.

Tourtelot, H. A., 1964. Minor-element composition and organic carbon content of marine and nonmarine shales of Late Cretaceous age in the western interior of the United States. Geochim. Cosmochim. Acta, 28:1579-1604.

Tourtelot, H. A., 1979. Black shale-Its deposition and diagenesis. Clays Clay Mineral, 27:313-321.

Tucholke, B. E., and Vogt, P. R., 1979. Western North Atlantic: Sedimentary evolution and aspects of tectonic history. In Tucholke, B. E., Vogt, P. R., et al., Init. Repts. DSDP, 43: Washington (U.S. Govt. Printing Office), 791-825.

van Andel, Tj. H., Thiede, J., Sclater, J. G., and Hay, W. W., 1977. Depositional history of the South Atlantic Ocean during the last 125 million years. J. Geol., 85:651-698.

Vine, J. D., and Tourtelot, E. B., 1969. Geochemical investigations of some black shales and associated rocks. U.S. Geol. Survey Bull., 1314-A.

1970. Geochemistry of black shale deposits-A summary report. Econ. Geol., 65:253-272.

Vinogradov, A. P., 1953. The Elementary Chemical Composition of Marine Organisms (Sears Found. Mar. Res. Mem. 2).

Vinogradova, Z. A., and Kovalskiy, U. V., 1962. Elemental composition of the Black Sea plankton. Akad. Nauk SSSR Dokl., 147: 1458-1460 (Russian).

Volkov, I. I., and Fomina, L. S., 1974. Influences of organic materials and processes of sulfide formation on distribution of some trace elements in deep-water sediments of Black Sea. In Degens, E. T., and Ross, D. A. (Eds.), The Black Sea-Geology, Chemistry, and Biology (Am. Assoc. Petrol. Geol. Mem.), 20:457-476.

von der Dick, H., Rullkötter, J., and Welte, D. H., 1983. Content, type, and thermal evolution of organic matter in sediments from 
the eastern Falkland Plateau, Deep Sea Drilling Project, Leg 71. In Ludwig, W. J., Krasheninnikov, V., et al., Init. Repts. DSDP, 71 (Pt. 2): Washington (U.S. Govt. Printing Office), 1015-1032.

Wedepohl, K. H., 1964. Untersuchung am Kupferschiefer in Nordwest deutchland; ein Beitrag zur Deutung der Genese bituminoger Sediment. Geochim. Cosmochim. Acta, 28:305-364.

Weissert, H., 1982. The environment of deposition of black shales in the Early Cretaceous: An ongoing controversy. In Warme, J. E.,
Douglas, R. G., and Winterer, E. L. (Eds.), The Deep Sea Drilling Project: $A$ decade of progress (Soc. Econ. Paleontol. Mineral. Spec. Publ.), 32:547-560.

Date of Initial Receipt: October 12, 1982 